\title{
ENSAIO PARA A TAXONOMIA DAS POLIPORÁCEAS
}

\section{A. Ribeiro Teixeira}

\section{INTRODUÇÃO}

Ao novel estudante de nossas poliporáceas carece um manual que o guie na determinação das espécies. Até mesmo lhe é dificultado o reconhecimento dos vários gêneros. Isso, porque não existe em português um trabalho que trate com especialidade da taxonomia dessa grande família. Em idiomas estrangeiros encontramos vários, como os de Bourdot e Galzin (3), Killermann (5), Lowe (7), Overholts $(9,10,11,12)$, e muitos outros, que tratam do :assunto, trazendo chaves e explicações essenciais. Porém, tais trabalhos nem sempre estão ao alcance de nossos estudantes, quer pela dificuldade na sua obtenção, quer devido aos idiomas em que estão escritos, nem sempre a tal ponto conhecidos que se tornem de fácil manejo.

Querendo sanar essa dificuldade, fazemos sair a lume êste trabalho, organizado de tal modo a proporcionar o máximo de ensinamentos, em um mínimo de palavras. Todavia, como o próprio título indica, isto não passa de um rensaio.

Com os conhecimentos básicos aqui explanados, esperamos que o restudante possa classificar, pelo menos até gênero, as "orelhas de pau" que fôr encontrando em seus passeios pelos bosques, ou outros lugares que tais. Quanto a chẹgar até espécie, dependerá de estudos mais aprofundados, de minuciosas e cansativas pesquisas bibliográficas, e de um frequente intercâmbio com especialistas estrangeiros.

O ideal seria possuirmos um herbário completo, ou o mais completo possivel, contendo as espécies brasileiras devidamente estudadas e classificadas, e de fácil acesso ao estudante. Tal, porém, não existe. Aqui e ali existem, ainda embrionàriamente, alguns herbários que poderão, em um futuro mais longínquo, oferecer as vantagens que dêles esperamos. A sua completação dependerá do interesse que fồ tomado pelo estudo dêstes fungos. Com o crescente intercâmbio com especialistas estrangeiros, poderemos obter, por permuta, preciosos espécimes devidamente classificados, -qiac no: serã) de inestimával valor para comparação com os que postirmos.

E mister incrementar-se a constituição de herbários micológicos nas -escolas. E da parte micológica, nada mais atraente e fácil para o aluno, que coletar "orelhas de pau". De cada coleta feita, uma parte será enviada .a especialistas, para identificação, enquanto a outra sofrerá os processos rotineiros, e seguirá para o seu respectivo lugar na coleção. Dentro em pouco, com a classificação feita por aquêles especialistas, teremos já um bom acervo de espécimes prontos para serem trabalhados. $\mathbf{E}$ assim, crescendo dia a dia, em tôdas as escolas do país, em breve teremos o tão ambicionado 
herbário completo, contendo as espécies brasileiras. Naturalmente, aqui falamos só das poliporáceas. Todavia, o mesmo deveria ser feito com respeito a tôda nossa flora micológica, e mais ainda : com tôda a nossa flora em geral.

Para completa compreensão dos têrmos usados na descrição das poliporáceas, e sua acertada aplicação, inserimos aqui um glossário ilustrado, para o qual chamamos a atenção do interessado.

$$
\text { *** }
$$

Desejamos externar aqui os nossos muito particulares agradecimentos ao Sr. José de Castro Mendes, desenhista-técnico, que de tão boa vontade se prontificou a nos auxiliar na execução das ilustrações.

\section{METODO DE PESQUISAS}

Os vários caracteres são examinados à vista desarmada, ou com o auxílio de uma lupa (de 10 a 20X), ou ainda sob o microscópio.

Para a realização dos cortes, e respectiva montagem em lâminaș, usamos o método à mâo livre, muito bem descrito por A. P. Viégas (13), e que se resume no seguinte, em se tratando de poliporáceas:

1. separar, com o auxílio de um canivete, um pequeno pedaço do corpo de frutificação a ser estudado;

2. colocar em álcool a $90 \%$, por 3 a 5 segundos, e, em seguida, em água distilada, por 5 a 10 minutos (para amolecer bem e facilitar o corte) $\left({ }^{*}\right)$;

3 . cortar longitudinalmente a medula de sabugueiro, ou outra semelhante, e colocar dentro o material, prendendo depois as partes com um pequeno elástico, ou com uma pinça especial;

4. fazer os cortes com a navalha comum, e colocá-los em vidro de relógio com água distilada ;

5. colocar os cortes em lâminas com gotas de :

a) ácido láctico a $50 \%$ (não altera a coloração das hifas);

b) sol. de potassa a 4-6\% (reage em certas hifas coloridas, tornando-as: ferrugíneas);

c) sol. de potassa a 4-6\%, mais sol. aquosa de eosina a $1 \%$ (corante) ; 6. cobrir com a lamínula.

Quando necessitamos de algum detalhe, para a obtenção do qual seja preciso o uso da objetiva de imersão, lutamos a lamínula, i.é, por meio de uma mistura, em partes iguais, de cera e parafina, prendemos a margem da lamínula à lâmina. Isso, para que não haja o perigo de a lamínula se. deslocar durante o ato da pesquisa, prejudicando a observação dos cortes.

(*) Tal passo não será necessário, em se tratando de material fresco. 


\section{POLYPORACE E}

A família Polyporacex faz parte do grande grupo dos basidiomicetos, e pode ser localizada como segue :

Os basidiomicetos dividem-se em dois grandes grupos: Heterobasidiomicetos e Homobasidiomicetos.

A. Heterobasidiomicetos - possuem heterobasídias, i.é, basídias septadas ou profundamente sulcadas, e de diferentes formas (Est. XXVI, fig. 33 a 37 ).

1. as basídias não se agregam para formar himênio. Não existe corpo de frutificação definido. São parasitas obrigatórios. Neste grupo entram os carvóes e as ferrugens. . ................ Ustilaginales e Uredinales

2. as basídias se agregam para formar o himênio. Há corpo de frutificação definido. São principalmente sapróbios ........Auriculariales, Tremellales e Dacryomycetales

B. Homobasidiomicetos - possuem homobasídias, i.é, basídias típicas, clavadas, não septadas (Est. XXVI, fig. 38 a 40).

1. se o himênio é sempre exposto, ou ao menos se expôc quando amadurecem os esporos, temos........ Hymeniales

2. se, por outro lado, o himênio permanece encerrado dentro do corpo de frutificação, mesmo depois que amadurecem os esporos, temos tôdas as ordens que compõem o grupo dos chamados.......... Gasteromicetos

Outra divisão também usada para os basidiomicetos, é aquela que os separa em três grupos, a saber :

A. Hemibasidiomicetos - aquêles que não têm himênio, nem corpo de frutificação definido.... Ustilaginales e Uredinales

B. Himenomicetos - aquêles que, possuindo himênio e corpo de frutificação definido, conservam aquêle sempre exposto, ou o expõem quando amadurecem os esporos........ ... Auriculariales, Tremellales, Dacryomycetales e Hymeniales

C. Gasteromicetos - aquêles que conservam o himênio encerrado dentro do corpo de frutificação, mesmo quando amadurecem os esporos...................Hymenogastrales, Phallales, Lycoperdales, Sclerodermatales e Nidulariales

A ordem Hymeniales, por sua vez, divide-se nas seguintes famílias :

1. himênio cobrindo por todos os lados uma superfície lisa, de clavas, ramificadas ou não................ Clavariacex

2. himênio unilateral, espalhado sôbre uma superfície lisa ou enrugada. 
3. himênio unilateral, desenvolvendo-se sôbre dentes.......Hydnaceæ

4. himênio unilateral, desenvolvendo-se sôbre lamelas...... Agaricaceae

5. himênio unilateral, desenvolvendo-se sôbre as paredes de poros..... a

a. frutificação gelatinosa, com poros pouco definidos........ b

a. frutificação não gelatinosa, com poros bem definidos......c

b. efuso-reflexa a séssil, nunca estipitada ; tubos muito rasos, irregulares, formados por paredes membranosas, seme-

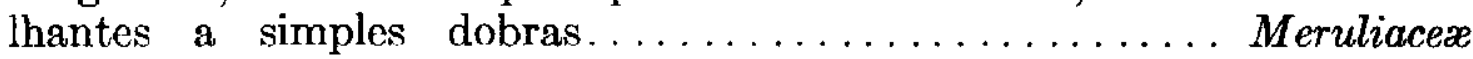

c. tubos profundos, de paredes bem definidas, perfeitamente ligados ao contexto, mas não ligados entre si, ou muito frouxamente apenas

Fistulinacex

c. tubos profundos, de paredes bem definidas, perfeitamente ligados entre si, mas frouxamente ligados ao contexto, podendo ser separados dêste em camada independente. Frutificação carnoso-mole

Boletaceæ

c. tubos profundos e bem definidos, perfeitamente ligados entre si e com o contexto. Os poros variam em forma, desde a circular até a lamelar. Frutificação geralmente coriácea a lenhosa

Polyporacex

Podemos, pois, definir as poliporáceas como sendo basidiomicetos com corpo de frutificação definido, con basídias que se agregam para formar o himênio ; êste permanece sempre exposto, e é formado por basídias que se dispõem sôbre as paredes de poros colocados em um só lado do corpo de frutificação ; tubos profundos e bem definidos, perfeitamente ligados entre si e ao contexto ; as basídias são clavuladas, não septadas, e trazem no tôpo quatro esterigmas que produzem, cada um, um esporo na extremidade; os esporos não se tornam septados ao germinar, germinando diretamente, sem produzir esporos secundários. O corpo de frutificação é de consistência geralmente coriácea a lenhosa, rija. Vegetam principalmente sôbre madeira.

No estudo da taxonomia das espécies desta família, temos que levar em consideração vários caraterísticos fundamentais, não só externos, mas também outros, anatômicos, só visíveis com o auxílio de uma boa lupa, ou mesmo do microscópio.

Os principais caraterísticos pelos quais nos baseamos na distinção das espécies, são : natureza anual ou perene ; se ressupinada ou não ; formato dos poros ; se há ou não continuidade entre a trama dos tubos e o contexto ; presença de estipe ; natureza da superfície do píleo ; consistência e coloração do contexto; caraterísticos gerais dos tubos; caraterísticos do himênio, tais sejam : presença de setas, cistídias, paráfises, etc. ; caraterísticos gerais dos esporos.

Tendo em mente todos êstes fatôres, vamos agora estudá-los mais detalhadamente. 
O corpo de frutificação pode ser : ressupinado, ou pileado. Quando pileado, pode ser : efuso-reflexo, séssil, ou estipitado. E efuso-reflexo, quando, possuindo uma parte ressupinada, se projeta além do substrato, para formar o pileo. E séssil, quando, sem possuir parte alguma ressupinada, não possui também estipe ; neste caso, o píleo fixa-se lateralmente ao substrato. E estipitado, finalmente, quando possui estipe.

Quanto ao estipe, pode ser : mesópodo, se o estipe é central ; pleurópodo, se o estipe é lateral ; de estipe excêntrico ; e de estipe dorsal. Pode ainda ser, segundo o comprimento do estipe, curto e longo-estipitado.

Segundo a sua forma, pode ser : dimidiado, flabeliforme, espatulado, petalóide, ou irregular. Se estipitado, reniforme ou circular.

Quando visto de perfil, em corte transversal, pode ser: aplanado, conchado, ungulado, imbricado. Quando central ou excêntricamente estipitado, o pileo pode ser : convexo, umbonado, deprimido, infundibuliforme.

Resumindo em chave, podemos dizer que os corpos de frutificação podem ser :

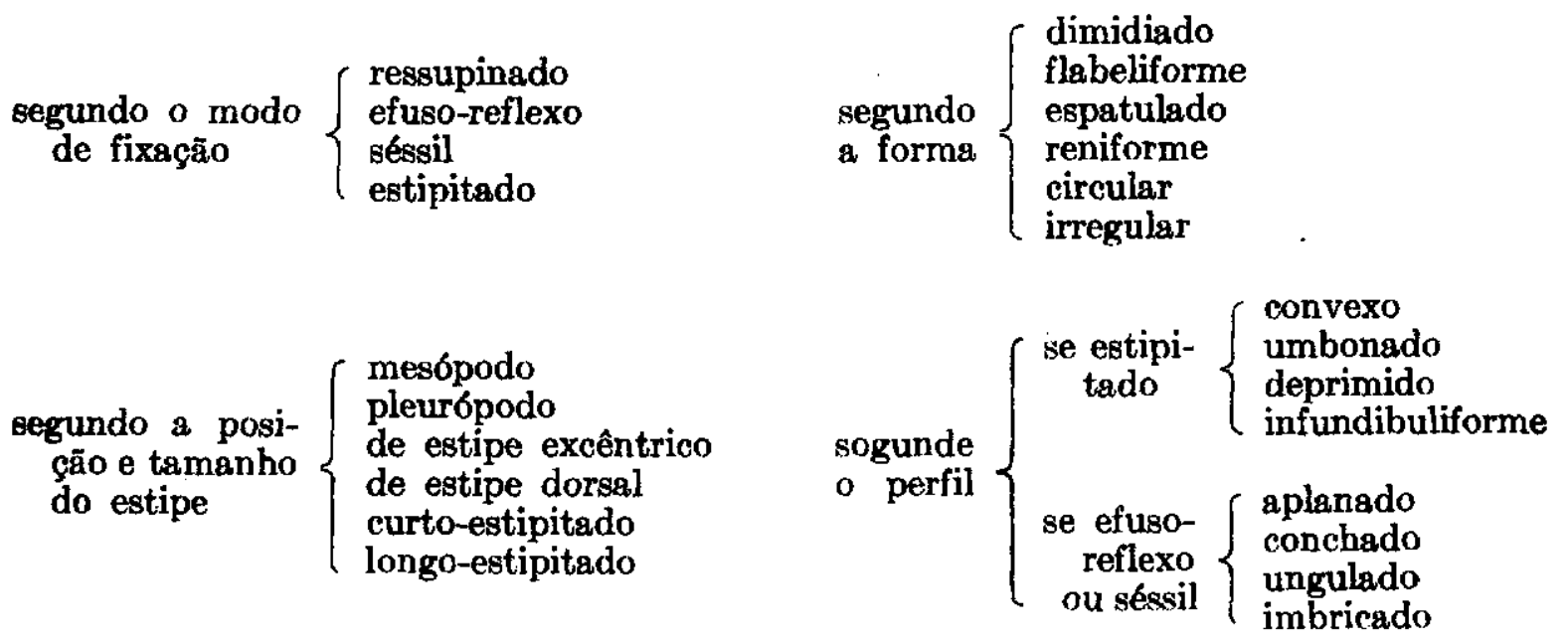

Vimos os vários nomes que toma um corpo de frutificação, quando tomado em seu todo. Agora vamos estudar cada uma de suas partes, e ver quais os nomes que recebem segundo os carateristicos que apresentarem.

Num corpo de frutificação completo, deveremos estudar:

\section{Estipe :}

colocação : central, excêntrico, lateral, dorsal ;

formato : curto ou longo ; cilíndrico, cônico, sinuoso, ereto, simples

ou ramificado;

superfície : pilosa, glabra, lacada, lisa, escabrosa, estriada ;

dimensões : 


\section{Píleo :}

superficie : pilosa, glabra, lacada, lisa, rimosa, sulcada; cstriada, zonada.

Coloração ;

margem: aguda, subaguda, obtusa ; fértil ou estéril em baixo ;

dimensões ;

\section{Contexto :}

dimensões ; coloração; consistêricia; zoração ;

hifas do cortexto: coloração, reação em KOH, dimensões, septação, espessura das paredes, ramificaçôes:

\section{Tubos :}

dimerisões ; coloração;

poros : coloração da superfície ; formato, dimensões e configuração dos bordos ;

dissepimento : coloração, dimensões, caraterísticos das hifas ;

\section{Himênio :}

Esta parte merece especial atenção, devido ao seu conteúdo. Além das basídias, que são as verdadeiras formadoras do himênio, notamos em muitos espécimes outros órgãos, estéreis, semelhantes às primeiras quanto ao formato, porém excedendo-lhes em tamanho. São as cistídias. Estas variam muito quanto à forma, e podem ser : clavadas, globosas, ciliridricas, cilindrico-veritricosas, e lanceoladas. Em outros espécimes encontramos certos corpos salientes, pontudos, em geral fortemente coloridos, denegridos, semelhantes a pequenos espinhos. São as setas. Estas, quanto à forma, podem ser : ventricosas, subuladas, direitas ou curvas. Variam muito quanto à frequência, de espécie para espécie.

Outras vêzes, encontramos filamentos que geralmento excedem de muito a altura das basídias. São as paráfises, que podem ser : simples ou ramificadas.

Em não poucos espécimes observamos uma interessante estrutura no himênio : um feixe de hifas muito delicadas, que, invadindo o himênio, ultrapassam a altura das basídias. São as medas (hyphal pegs dos americanos). Estas podem tomar formas variadas, de espécic para espécie, prevalecendo, todavia, a cônica e cilíndrico-cônica.

Chegamos, finalmente, a um dos mais importantes órgãos para ser estudado, o qual, aliás, é de absoluta importância para separar inúmeras espécies, e até mesmo gêneros : os esporos. Estes devem ser estudados segundo sua coloração, que pode variar desde a hialina, até ferrugíneoescura. Segundo a forma, variam de cilíndricos até globosos, prevalecendo os tipos intermediários: ovóides, subglobosos, elipsóides e cilíndrico-elipsóides.

Resumindo tudo quanto dissemos a respeito do himênio, temos: cistídias :

quanto a forma : clavadas, globosas, cilindricas, cilíndrico-ventricosas, lanceoladas ;

quanto a incrustações : incrustadas, lisas. 
setas :

quanto à forma: ventricosas, subuladas, direitas, curvas ; medas :

quanto à forma: cônicas, cilíndrico-cônicas ;

esporos :

quanto à coloração : hialinos, coloridos ;

quanto à forma : globosos, subglobosos, ovóides, elipsóides, cilíndricoelipsóides, cilíndricos, alantóides, reniformes ;

quanto à parede: de parede simples, dupla, espêssa, imperceptível.

\section{GENEROS}

Observando as inúmeras espécies aqui contidas, salta-nos logo à vista a grande diferença de consistência entre os vários grupos de seus componentes. Por outro lado, notamos o modo comò se fixam sôbre o substrato. Alguns esparramam-se sôbre êle, sem nunca formarem o píleo, i.é, são sempre ressupinados. Tais espécimes integram as inúmeras espécies do gênero Poria, de que temos exemplo em Poria pulchella (Schw.) Cooke (Est. XXI). Alguns espécimes de outros gêneros poderão apresentar-se ressupinados ; porém, será um caso esporádico em tal espécie, que habitualmente apresentará seus componentes na forma efuiso-reflexa, séssil ou estipitada.

Se cortarmos um corpo de frutificação em seu sentido transversal, ou seja, no sentido longitudinal dos poros, vamos notar que os membros desta família dividem-se em dois grupos: A) aquêles em que os tubos formam uma camada bem distinta do contexto; B) aquêlos em que a trama dos tubos se confunde com a do contexto, e os tubos penetram neste a profundidades desiguais.

Examinando espécimes pertencentes ao grupo A, hotamos que alguns têm várias camadas de tubos, enquanto outros apresentam uma única. Aqui também deparamos com um importante fator que separa outros gêneros; Aquêles que apresentam várias camadas de tubos, são perenes, i.é, vivem muitos anos sôbre o seu hospedeiro, sendo que cada ciclo vegetativo acrescenta-lhe; mais uma camada de tubos. Pertencem a êste grupo as poliporáceas chamadas fomóideas.

Por outro lado, os que apresentam uma só camada de tubos são anuais, i.é, o seu ciclo de vida se limita a um período vegetativo único, findado o qual êle morre. A êste grupo pertencem as espécies chamadas

\section{poliporóideas.}

Examinando, agora, espécimes pertencentes ao grupo B, notamos que todos têm uma :ó camada de tubos, e se diferenciam essencialmente pela conformação dos poros. A êste grupo pertencem as poliporáceas chamadas trametóideas. 


\section{Vejamos cada grupo de per si :}

Fomóideas : Dois gêneros são incluídos neste grupo : Ganoderma e Fomes. O primeiro carateriza-se principalmente pelos seus esporos muito singulares, completamente diferentes dos de todos os outros espécimes. dos demais gêneros. São esporos ovóides, cobertos por uma espêssa camada gelatinosa, papilada a enrugada, camada essa que forma um ápice obtuso a subagudo na extremidade distal, o qual, na maioria das vêzes, se apresenta truncado (Est. XXVI, fig. 50). E um esporo muito típico, que não se confunde com nenhum outro. Os espécimes pertencentes a êste gênero apresentam-se, geralmente, cobertos por uma crosta lisa, lacada, brilhante, amarelada a avermelhada, algumas vêzes castanho-vinosa, também muito caraterística. Como exemplo, temos o Ganoderma sp. (Est. X e XI). Essa crosta lacada, porém, pode faltar em fungos de várias espécies do gênero, sendo então substituída por outra, parda a acinzentada, sem brilho. Temos, como exemplo disso, o Ganoderma applanatum (Pers.) Pat. (Est. VIII e IX).

Quanto ao gênero Fomes, compreende tôdas aquelas espécies fomóideas que não possuirem o caraterístico esporo de Ganoderma. Como exemplo, para êste gênero, temos: Fomes rimosus (Berk.) Cooke (Est. V, VI e VII).

Poliporóideas : Aqui vamos encontrar um grupo de espécies cujos componentes se apresentam ora estipitados, ora sésseis, ora efuso-reflexos ; todos, porém, possuindo poros circulares a angulares, relativamente pequenos. Pertencem a êste grupo as numerosas espécies do gênero Polyporus. Temos, como exemplo, Polyporus leorotis Kalchb. (Est. XVII e XVIII), e P. gilvus (Schw.) Fries (Est. XIX e XX).

Trametóideas : Vários gêneros são incluídos aqui, e são separados uns dos outros pela constituição e conformação dos poros. Se êstes são pequenos, arredondados ou angulares, temos o gênero Trametes, como, por exemplo, Trametes caperata Berk. (Est. XXII e XXIII). Se os poros são grandes, aproximadamente hexagonais, temos o gênero Hexagona: por exemplo, Hexagona variegata Berk. (Est. XII e XIII). Se, porém, êsses. hexágonos são muito alongados, algumas vêzes aproximando-se mesmo de verdadeiros lozangos, em espécimes sempre com estipe lateral, temos: o gênero Favolus ; por exemplo, Favolus brasiliensis Fries. (Est. III e IV). Se, agora, os poros forem alongados, dedalóides, irregularmente distribuídos, o gênero será Daedalea, de que temos um bom exemplo em Daedalea quercina (L.) Fries (Est. I e II). Porém, nem sempre os poros parecem ser tal. Ás vêzes, as paredes laterais se rompem em sequência uniforme, fazendo com que os tubos coalesçam, formando verdadeiros sulcos que dão ao todo uma aparência de lamelas concêntricas. Esta feição singular de poros cara-teriza as espécies do gênero Cyclomyces, do qual, infelizmente, não temos em mãos sequer um único espécime para ilustrar [o desenho dado na Est. XXV, fig. 17, foi adaptado de uma fotografia de Lloyd (6)]. Outras vêzes,. os poros são tão alongados no sentido radial, que dão a aparência de verdadeiras lamelas, como as de Agaricaceæ. Tais poros caraterizam o gênero Lenzites, de que temos um bom exemplo em Lenzites repanda (Mont.) Fries. (Fst. XIV, XV e XVI). 
Podemos resumir o que acabamos de dizer, na seguinte chave de classificação dos gêneros da família Polyporaceæ.

A. corpo de frutificação sempre ressupinado $\ldots \ldots \ldots \ldots \ldots \ldots$ Poria

B. corpo de frutificação efuso-reflexo, séssil ou estipitado.........

1. tubos em camada distinta do contexto................ 2

1. tubos não formando camada distinta do contexto, e usual-

mente penetrando a profundidades desiguais no mesmo

(tramet6ideas)

2. esporóforo caraterìsticamente perene, composto de várias camadas de tubos, formadas cada ano (fomóideas) ........5

2. esporóforo geralmente anual, não típicamente perene (poliporóideas)

Polyporus:

3. tubos coalescem lateralmente, formando verdadeiros sulcos que dão ao todo uma aparência de lamelas concêntricas ;

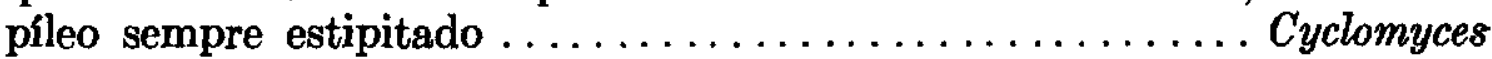

3. tubos não coalescem lateralmente. .................

4. poros circulares a angulares . ............... Trametes

4. poros grandes, hexagonais $\ldots \ldots \ldots \ldots \ldots \ldots \ldots \ldots$ Hexagona

4. poros hexagonais muito alongados, tendendo a lozangulares ; píleos sempre pleurópodos . . . . . . . . . . . . .

4. poros alongados, dedalóides, irregulares $\ldots \ldots \ldots \ldots \ldots$ Daedalea

4. poros aproximando-se de verdadeiras lamelas radiais ... Lanzites

5. esporo liso, de parede simples, hialino ou colorido ....... Fomes

5. esporo minutamente papilado a rugoso, de parede dupla, i. é, provido de episporo com ápice geralmente truncado .. Ganoderma

\section{ESPECIES}

Terminado o estudo geral sôbre a classificação do gênero, passamos agora às espécies.

Para a determinação dos gêneros, lançamos mão de caracteres, em sua grande maioria, fàcilmente distinguíveis a ôlho nu. Agora, porém, para a classificação das espécies, temos que usar, além dêsses, outros caraterísticos sòmente visíveis com o auxílio de uma boa lupa, ou de um microscópio. Assim é que, para a distinção das espécies, dentro de cada gênero, temos que observar: 1) se o corpo de frutificação é ressupinado, efusoreflexo, séssil ou estipitado ; 2) se estipitado, caraterísticos gerais do estipe ; 3) formato e dimensóes do píleo ; 4) caraterísticos gerais da superfície ; 5) consistência do píleo ; 6) caraterísticos da margem ; 7) número de poros por milímetro linear ; 8) formato e dimensões dos poros ; 9) consistência e coloração do contexto ; 10) dimensóes do contexto ; 11) caraterísticos gerais das hifas do contexto; 12) coloração dos tubos quando em corte ; 
13) profundidade dos tubos ; 14) (araterísticos do dissepimento ; 15) caraterísticos das cistídias ; 16) caraterísticos das setas ; 17) carat. das medas ; 18) carat. das paráfises ; 19) carat. das basídias ; 20) carat. dos esporos.

Como vemos, temos nada menos que $\mathbf{2 0}$ grupos de caracteres principais sôbre os quais são baseadas as diagnoses das espécies. Cada grupo dêstes, porém, pode ter um grande número de variaçóes, como podemos ver pelo que descrevemos atrás. Assim sendo, dá margem verdadeiramente gigantesca para o número de espécies diferentes, considerando-se as combinações possíveis entre todos os fatôres cuja soma é usada como diferenciação específica.

Temos agora todos os dados necessários para a classificação de qualquer espécie da família Polyporaceæ. Podemos, seguindo as normas aqui explanadas, descrever qualquer espécie, con tôda a minuciosidade, e empregando os têrmos certos, usuais. Depois de possuirmos a descrição detalhada, com ilusitraçóes macro e microscópicas, o que nos restará a fazer, para dar o nome certo ao espécine em estudo, é percorrer a literatura sôbre o assunto, e encontrar a diagnose que se adapte à nossa descrição, já que não possuimos, ainda, um eficiente herbário à mão, pelo qual poderíamos determinar, por simples comparação, o nosso material.

\section{EXEMPIOS DE IDESCRIÇÃO}

\section{Daedalea quercina (L.) Fries}

(Est. I, II)

PÍLEO : (Est. I) séssil, tendendo ao ungulado; raramente imbricado; $3-8 \times 3-12 \mathrm{~cm}$, por $2-5 \mathrm{~cm}$ espêtisos.

superficie : castanho-clara a acinzentada, glabra a minutamente pubescente (em píleo: mais jovens); suave e concêntricamente sulcada, às vêzess um tanto escabrosa.

margem : obtusa ; estéril em baixo, ou estreitamente fértil apenas.

CONTEXTO : suberoso ; rastanho-rlaro a amarelarlo, elareando para os poros; zonado, $0,5-3 \mathrm{~cm}$ espêsiso.

hifas do contexto: (Kst. II, fig. a) ligeiramente coloridas; suavemente sinuosas, pouco ramificadas, apresentando septos nas junções das ranificaçōes; de parede grossa e lúmen estreito a médio ; 2-5u de diâmetro.

TUBOS : (Est. I) de mesma côr que o contexto, 0,5-2cm longos.

poros : (Est. I) francamente dedalóides, às vêzes tendendo para lenzitóides; $1 \mathrm{~mm}$ de ahertura, por 2-10 $\mathrm{mm}$ longus, na média; do bordos lisos a apenas ondulador, obtusos; espêssos do $0, \tilde{0}-1.5 \mathrm{~mm}$. dissepimento : formado por hifas semelhantes às do contexto.

HIM ENIO : (Fst. II)

cistidias e setas, inexistentes;

basídias : não observadas ;

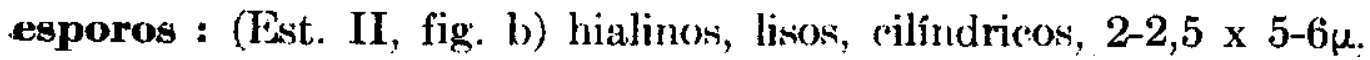


Observações : Descrição baseada nos materiais n. ${ }^{\circ} 666,1791$ e 1863 do Herbário Micológico da Secção de Botânica, Inst. Agron. Campinas, Est. S. Paulo.

Favolus brasiliensis Fries

(Est. III, IV)

ESTIPE : (Est. III, fig. a) lateral a muito raramente excêntrico ; curto de $0-2 \mathrm{~cm}$, com $0,5-1 \mathrm{~cm}$ de diâmetro.

PILEO : (Est. III) pleurópodo a muito estreita e raramente de estipe excêntrico ; coriáceo-flexível, flabeliforme a dimidiado, $2-15 \times 3-20 \mathrm{~cm}$, por 2-6mm espêsso.

superfície : glabra; esbranquiçada a amarelada, tornando-se mais escura ao secar ; radialmente estriada em delicadas estrias.

margem : às vêzes de côr escura, queimada ; aguda, fértil em baixo.

CONTEXTO : esbranquiçado, 0,5-2mm espêsso.

hifas do contexto : (Est. IV, fig. a) levemente citrinas, ramificadas, não septadas, de parede grossa e lúmen estreito a médio ; tortuosas, variam de $2-5 \mu$ de diâmetro.

TUBOS: mais escuros que a superfície, $1-4 \mathrm{~mm}$ profundos.

poros : (Est. III, fig. b) longo-hexagonais, 3-10 x 1-2mm, de bordos serrilhados a lacerados, agudíssimos.

dissepimento : formado por hifas semelhantes às do contexto.

HIMENIO : (Est. IV)

cistídias e setas, inexistentes.

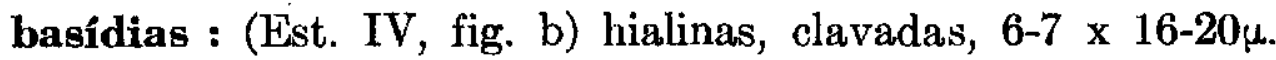

esporos : (Est. IV, fig. c) hialinos, cilíndricos, multi-gutulados, 2,5-3,5 $\mathrm{x} 7-11 \mu$.

Observação : Descrição baseada nos materiais n. ${ }^{0} 4406$ e 4846 , do Herb. Mic. da Secção de Botânica, I. A., Campinas, Est. S. Paulo.

Fomes rimosus (Berk.) Cooke (Est. V, VI, VII)

PÍLEO : (Est. V, VI) séssil, aplanado a ligeiramente ungulado, 6-15 x 14$25 \mathrm{~cm}$, por $2-8 \mathrm{~cm}$ espêsso; muito raro imbricado.

superficie : quando o píleo ainda é novo, ela é castanho-escura, pubescente ; ao ficar adulto, torna-se cinzento-denegrida, glabra, profunda e concêntricamente sulcada ; com a idade, vai ficando rimosa, ou seja, com a crosta tôda partida em pequeninas fendas; tem os bordos mais claros.

margem : obtusa, pubescente, estéril, em baixo.

CONTEXTO : (Est. VI, fig. c) castanho-amarelado, zonado, lenhoso, espêsso de $2-4 \mathrm{~cm}$, homogêneo para os bordos, irregular para a inserção 
do pileo, podendo apresentar, nesse lugar, estrias negras, de substância duríssima.

hifas do contêxto : (Est. VII, fig. a) de dois tipos : a) não ramificadas, fuscas, lisas, de paredes não muito espêssas e lúmen largo a médio; apresentam septos, sendo que as de menor diâmetro mostram maior frequência dêles que as mais grossas ; $3-7 \mu$ de diâmetro. b) muito ramificadas, um tanto sinuosas, mais claras que as` primeiras, de lúmen muito estreito ; $1,5-3 \mu$ de diâmetro, pouco abundantes. Quando montadas em $\mathbf{K O H}$, essas hifas apresentam uma forte coloração ferrugínea; e, quando em ácido láctico, apresentam-se amarelo-citrinas.

TUBOS : (Est. VI, fig. c ; VII, fig. b) castanho-amarelados, indistintamente estratificados, sendo que as camadas variam de $2-6 \mathrm{~mm}$ de espessura ; o interior apresenta-se de coloração amarelo-enxofre.

poros : castanho-amarelados, circulares a ligeiramente alongados, 4-5 por $\mathrm{mm}, 130-200 \mu$ de diâmetro, de bordos inteiros.

dissepimento : (Est. VII, fig. $b$, c) de espessura irregular, de 30-150 $\mu$; hifas semelhantes às do contexto, de $1,5-2,5 \mu$ de diâmetro.

HIMENIO : (Est. VII)

cistídias e setas, inexistentes ;

basídias : hialinas, clavadas, $3,5 \times 7 \mu$.

esporos : (Est. VII, fig. d) amarelados, subglobosos, apresentando um lado achatado; parede espêssa, fusca ; lisos, 1-gutulados, $3,5-4 \times 4,5-5 \mu$.

Observações : Descrição baseada nos materiais n. ${ }^{\circ} 4365$ e 4387 , do Herb. Mic. da Seç̧ão de Botânica, I. A., Campinas, Est. S. Paulo.

\section{Ganoderma applanatum (Pers.) Pat. (Est. VIII, IX)}

PILEO : (Est. VIII) séssil, aplanado, lenhoso, dimidiado, perene, 8-15 x $10-20 \mathrm{~cm}$, no geral $1-2,5 \mathrm{~cm}$ espêsso, algumas vêzes alcançando até 5-6cm de espessura, quando com muitas camadas de tubos.

superfície : (Est. VIII, fig. a) glabra, castanho-clara a acinzentada suave e concêntricamente sulcada em sulcos apenas perceptíveis, delicada e concêntricamente zonada de castanho-claro; coberta por crosta córnea, difìcilmente perfurável à unha, de coloração parda a acinzentada, fosca.

margem : (Est. VIII, fig. b) de mesma côr que a superfície, inteira, lisa a levemente sinuosa. obtusa, estéril em baixo.

CONTEXTO : (Est. VIII, fig. d) castanho-escuro, amarelecido junto a crosta da superfície, corticoso-rijo, azonado, 1-3mm espêsso na parte aplanada do píleo, e de espessura variável junto à inserção.

hifas do contexto : (Est. IX, fig. a) castanho-amareladas, pouco ramificadas, de paredes espéssas e estreito lúmen, levemente 
sinuosas, variando, em média, de $2-5 \mu$ de diâmetro. Não sofrem reação quando montadas em KOH.

TUBOS : (Est. VIII, fig. c) nìtidamente estratificados, em píleos de vários anos; mais claros que o contexto, esbranquiçados no interior, até $8 \mathrm{~mm}$ longos.

poros : (Est. IX, fig. b) cinzento-amarelados a castanho-claros, circulares, 100-160 $\mu$ de diâmetro, 4-5 por $\mathrm{mm}$, de bordos lisos, inteiros.

dissepimento : (Est. IX, fig. c) de espessura mais ou menos uniforme, de $40-60 \mu$; formado por hifas semelhantes às do contexto, de 1,5-2 $\mu$ de diâmetro.

HIMENIO : (Est. IX) contém hifas hialinas, simples ou ramificadas, que se emaranham pelo dissepimento e se estendem, às vêzes, além das basídias, penetrando no lúmen dos tubos, e que têm, em média, $1 \mu$ de diâmetro (Est. IX, fig. e).

cistídias : (Est. IX, fig. d) hialinas, ventricosas, possuindo, às vêzes, a extremidade afilada e alongada de até $20 \mu ; 5-10 \times 10-40 \mu ;$ a extremidade afilada é de $1,5-2 \mu$ de diâmetro.

setas : não existentes.

basídias : não observadas.

esporos : (Est. IX, fig. f) ferruginoso-claros, típicos de Ganoderma; episporo nulo, apresentando apenas o ápice truncado, hialino ; endosporo de parede espêssa, fusca, 4-5 x 6-8 $\mu$, 1-gutulado.

Observações : Descrição baseada no material n. 1130 do Herb. Mic. da Secção de Botânica, I. A., Campinas, Est. S. Paulo.

PILEO : (Est. X) séssil, aplanado, leve, dimidiado, pouco e raramente imbricado, $10 \times 12 \times 1-2 \mathrm{~cm}$.

superfície : (Est. X, fig. a) coberta por uma laca brilhante, castanhoferrugínea-escura para o centro, tornando-se mais clara até amarelada nos bordos; concêntricamente sulcada por muitos e rasos sulcos (4-5 por $\mathrm{cm}$ ). O verniz é muito delgado e frágil, sendo fàcilmente perfurável à unha.

margem : (Est. $X$, fig. b) obtusa, inteira, estéril em baixo ; amarelada, às vêzes tornando-se até creme.

CONTEXTO : castanho-escuro, chocolate, mais claro junto à crosta da superfície, sendo desta separado por uma finíssima camada amareloferrugínea ; mais escuro junto aos tubos, de consistência frouxa, corticosa.

hifas do contexto : (Est. XI, fig. a) castanho-ferrugíneas, não reagem em $\mathrm{KOH}$; de paredes espêssas e lámen estreito a médio ; pouco ramificadas, $5-7 \mu$ de diêmetro. 
TUBOS : castanho-escuros, pouco mais claros que o contexto, às vêzes esbranquiçados dentro, $5-10 \mathrm{~mm}$ longos, não estratificados.

poros : (Est. X, fig. c ; XI, fig. b) circulares a alongados, a princípio esbranquiçados, tornando-se castanho-escuros mais tarde ; 4-5 por $\mathrm{mm}, 120-200 \mu$ de diâm., de bordos inteiros.

dissepimento : (Est. XI, fig. c) de espessura um tanto irregular, variando de 50 a $250 \mu$; formado por hifas semelhantes às do contexto, porém mais estreitas.

\section{HIM ENIO : (Est. XI)}

cistídias e setas, inexistentes.

basídias : nâo observadas.

esporos : (Est. XI, fig. d) típicos do gênero. O episporo, hialino, é pontuado, geralmente truncado no ápice, e varia em espessura, de 0,5 a $1 \mu$, sendo que pode atingir ate $2 \mu$ na parte truncada; e, se o ápice não foi truncado, pode atingir até $4 \mu$ nesse ponto.

$O$ endosporo possui parede espêssa, fusca ; é elíptico-ovóide, 1-gutulado, e mede 4,5-5,5 x 8-9 $\mu$.

Observações : Diagnose bascada no material n. ${ }^{\circ} 22842$ do Herb. do Inst. Bot. de São Paulo, Est. S. Paulo.

\section{Hexagona variegata Berkeley}

(Est. XII, XIII)

PÍl.FO : (Est. XII) subcoriáceo, efuso-reflexo, parte reflexa no geral aplanada; $1-5 \times 1,5-8 \mathrm{~cm}$, por $1-4 \mathrm{~mm}$ de espessura.

superfície : velutina, concêntricamente zonada em várias côres, predominando as zonas em côr violeta-denegrida; radialmente enrugada en rugas abundantes e muito delicadas.

margem : castanho-clara, estéril em baixo.

CONTEXTO : variando de $0-4 \mathrm{~mm}$, zonado em estreitas zonas, castanhoclaro.

hifas do contexto : (Est. XIII, fig. a) castanho-amareladas, de parede estreita e largo lúmen, um tanto sinuosas, não ramificadas, variando de $3-6 \mu$ de diâmetro.

TUBOS : castanho-claros, $0-1,5 \mathrm{~mm}$ longos.

poros : (Est. XII, fig. c ; XIII, fig. b) castanho-claros, circulares a nitidamente hexagonais, $500-750 \mu$ de diâmetro; de bordos lisos, inteiros.

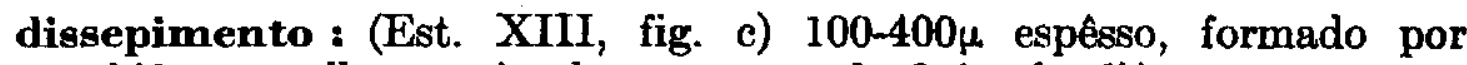
hifas semelhantes às do contexto, de $3-4 \mu$ de diâmetro.

\section{HIMENIO :}

cistídias e setas, não existentes.

paráfises : (Est. XIII, fig. d) hialinas, raras, não se prolongam além das basídias, $2-3 \mu$ de diâmetro. 
basídias : (Est. XIII, fig. e) hialinas, abundantíssimas, possuindo 4 esterigmas 7-10 $\mu$ longos. Apresentam inúmeras gotas de substância oleosa, que variam de $1-2 \mu$ de diâmetro. Medem, na média, 35u de comprimento e 8-11 $\mu$ de diâmetro.

medas : (Est. XIII, fig. f) cônicas, não muito abundantes, projetando-se de $100-150 \mu$ além das basidias.

esporos : (Est. XIII, fig. g) hialinos, cilíndrico-elipsóides; multigutulados quando jovens, 1-gutulados quando já maduros, 12-15 x $4,5-5,5 \mu$.

Observações : Descrição feita a partir do material 4388 do Herb. Mic. Secc. Bot. I. A., Campinas, Est. S. Paulo.

\section{Lenzites repanda (Mont.) Fries (Est. XIV, XV, XVI)}

ESTIPE : (Est. XIV, fig. a ; XV, fig. a) lateral, isabelino, glabro, curtíssimo, 1-6mm longo ; a base esparrama-se sôbre o substrato, formando um círculo mais ou menos regular, de $2-4 \mathrm{~cm}$ de diâmetro. Às vêzes, parece ser central ou excêntrico ; isso acontece quando há anastomose das extremidades do píleo, as quais se encontram circundando o estipe ; essa anastomose nem sempre é perfeita, sobrando um vão (Est. XV).

PÍLEO : (Est. XIV, XV) suberoso-coriáceo, curtíssimo-estipitado, reniforme ; $5-10 \times 8-15 \mathrm{~cm}$, por $1-4 \mathrm{~mm}$ espếsso.

superfície : (Est. XIV, fig. b ; XV, fig. b) glabra, isabelina, às vêzes apresentando-se um tanto tuberculosa, outras vêzes suave e radialmente ondulada ; concêntricamente zonada em suavíssimas zonas: mais visíveis para a margem.

margem : (Est. XIV, fig. c ; XV, fig. c) aguda a semi-aguda, fértil em baixo, ou estreitamente estéril, de bordos sinuosos.

CONTEXTO : branco, quando sêco, amarelado, quando umedecido ; corticoso-frouxo; zonado em zonas concêntricas, 2 por $\mathrm{cm}$, apenas: e fracamente perceptíveis quando umedecemos o material, ou em espécimes frescos; $0,5-2 \mathrm{~mm}$ espêsso.

hifas do contexto: (Est. XVl, fig. a) ligeiramente citrinas, não sofrem reação em $\mathrm{KOH}$; de paredes grossas e estreitíssimo lúmen. São de duas qualidades: a) lisas, muito longas, sem ramificaçōes nem septos, variam de 4-6 $\mu$ de diâmetro ; b) onduladas a muito sinuosas, muito ramificadas, sem septos, variam de $1,5-3 \mu$ de diâmetro.

TUBOS : (Est. XIV, fig. d ; XV, fig. d) uniformemente lamelares, da margem do píleo até o estipe; $0,5-2 \mathrm{~mm}$ profundos, pouco mais escuros que a superfície do pileo.

poros: longos de $1-15-20 \mathrm{~mm}$, de bordos suavemente dentados a serrilhados.

dissepimento : (Est. XVI, fig. b) espêsso de 40-200 $\mu$; formado por hifas semelhantes às do contexto, prevalecendo as do tipo $b$, i.é, mais finas e muito ramificadas. 
HIMENIO : (Est. XVI) contém hifas hialinas, lisas a tortuosas, ramificadas, providas de ganchos de ligação, e que variam de $1-2, \pm 5 \mu$ de diâmetro (fig. c).

cistídias e setas, não existentes.

basídias : (Est. XVI, fig. d) hialinas, clavuladas, $4 \times 18 \mu$.

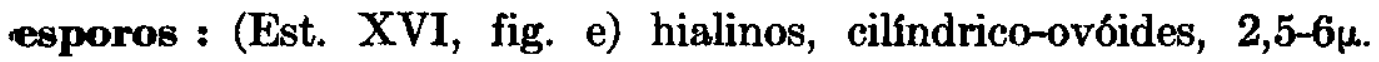

Observações : Descrição feita baseada no material n. 4506 do Herb. Mic. Seç̧ão Bot. I. A., Campinas, Est. S. Paulo.

POLYPORUS LEONOTIS Kalchb.

(Est. XVII, XVIII)

PÍlEO : (Est. XVII) séssil, raro efuso-reflexo, dimidiado, aplanado-conchoíde, leve, 4-6 x 7-10 cm, espêsso de 3-6mm.

superficie : (Est. XVII, fig. a) densamente coberta por pêlos castanhoamarelados, algumas vêzes denegridos, longos de 5-10 $\mathrm{mm}$, emaranhados e deitados para a margem, tendo um grande sulco concêntrico, a $1-1,5 \mathrm{~cm}$ dos bordos.

margem : (Est. XVII, fig. b) castanho-avermelhada, obtusa a aguda, estreitamente estéril em baixo ; de bordos lisos a ásperos, às vêzes denegridos, ondulados.

CONTEXTO : geralmente exíguo ; fibroso, corticoso, castanho bem claro, 0,5-2mm espêsso.

hifas do contexto : (Est. XVIII, fig. a) amarelo-citrinas quando montadas em ácido láctico, reagem pouco em $\mathrm{KOH}$, tornando-se pouco mais escuras. De dois tipos : a) muito sinuosas e ramificadas, de estreitíssimo lúmen, 1,5-3 $\mu$ de diâmetro ; b) lisas, não ramificadas, de paredes grossas e lúmen estreito a médio, 4-6 $\mu$ de diâmetro.

TUBOS : (Est. XVII, fig. c, d) pouco mais escuros que o contexto, às vêzes esbranquiçados no interior, até $5 \mathrm{~mm}$ longos.

poros : (Est. XVII, fig. d ; XVIII, fig. b) de superfície às vêzes amarela, geralmente de mesma côr que os tubos ; circulares, 5-6 por $\mathrm{mm}$; quando em corte, $150-200 \mu$ de diâmetro; de bordos inteiros.

dissepimento : (Est. XVIII, fig. c) de espessura regular, 40-70 $\mu$, formado por hifas amarelo-citrinas, lisas, de lúmen estreito e paredes grossas, $2-3 \mu$ de diâmetro.

HIMÊNIO : (Est. XVIII)

cistídias : (fig. d) hialinas, ventricosas, raras, $5 \times 20-25 \mu$.

basídias : (fig. e) hialinas, clavadas, $5 \times 10-12 \mu$.

medas : (fig. f) poucas, cônicas, $17-22 \mu$ longas, por $20-30 \mu$ de base. esporos : (fig. g) hialinos, lisos, cilíndricos, 2-3 $\times 6,5-8,5 \mu$.

Observações : Descrição feita baseada no material n. 2100 do Herb. Mic. Seç̧ão Bot. I. A., Campinas, Est. S. Paulo. 
PILEO : (Est. XIX) séssil a efuso-reflexo ; dimidiado a irregular, aplanado, algumas vêzes imbricado, $1-8 \times 2-12 \times 0,2-2 \mathrm{~cm}$.

superfície : castanho-ferrugínea, glabra, concêntrica e levemente sulcada, um tanto rugosa, às vêzes minutamente tuberculosa.

margem : obtusa a aguda, sinuosa, geralmente de um tom mais amarelado que a superfície; minutamente pubescente, estéril em baixo.

CONTEXTO : castanho-amarelado, corticoso, 1-10mm espêsso.

hifas do contexto : (Est. XX, fig. a) amarelo-citrinas, reagem em $\mathrm{KOH}$, tornando-se ferrugíneas ; não ramificadas, de paredes não muito espêssas, com largo lúmen; apresentam septos, mas não em grande abundância; as mais estreitas são mais sinuosas; $3-5 \mu$ de diâmetro.

TUBOS : (Est. XX, fig. b, c) de mesma côr que o contexto, raramente estratificados, de 1-10 $\mathrm{mm}$ longos.

poros : circulares a ligeiramente alongados, de bordos algumas vêzes dentados ; 6-8 por $\mathrm{mm}, 90-120 \mu$ de diâmetro.

dissepimento : (Est. XX, fig. b, d) de espessura irregular variando de 10 a $100 \mu$, formado de hifas semelhantes às do contexto, apenas mais delgadas, de $2-3 \mu$ de diâmetro.

\section{HIMÊNIO : (Est. XX)}

setas : (fig. e) abundantíssimas, subuladas a lanceoladas, denegridas, 5-8 $\times 20-25 \mu$.

cistídias : (fig. f) ventricosas, $5-8 \mu$ de diâmetro na parte bojuda, e projetando-se até 15-20 $\mu$ dentro do lúmen dos tubos; algumas apresentam prolongamentos filiformes de até 20-30 $\mu$ longos.

paráfises : (fig. g) cilíndrico-filiformes, não ramificadas, algumas vêzes apresentando-se incrustadas em seu comprimento com cristais irregulares que variam de 1-1,5 $\mu$ de diâmetro ; $2-3$ x 20-40 $\mu$.

esporos : (fig. h) hialinos, lisos, cilíndrico-elipsóides, 1-gutulados, medindo, na média, $2,5-4,5 \mu$.

Observações : Descrição baseada no material n. ${ }^{\circ} 1112$ do Herb. Mic. Secção Bot. I. A., Campinas, Est. S. Paulo.

\section{Poria pulchella (Schw.) Cooke}

(Est. XXI)

HIMENOFORO : irregularmente esparramado sôbre o substrato ; com uma ou mais camadas de tubos.

margem : com limites bem definidos, onde se nota uma delicada pubescência; fértil a estreitamente estéril.

CONTEXTO : insignificante, pràticamente nulo ; apenas uma fina camada de hifas citrinas (Est. XXI, fig. a), muito ramificadas, de duas quali- 
dades : a) sem septos, de parede grossa e estreito lúmen (fig. 1) ; b) septadas, de parede estreita e largo lúmen (fig. 2). Ambas variam. de $1,5-3 \mu$ de diâmetro.

TUBOS : amarelados, $1-1,5 \mathrm{~mm}$ longos.

poros : (Est. XXI, fig. b) amarelados, de superfície um tanto enrugada, muito irregular, seguindo a "topografia" do substrato ; circular a alongada, 5-6 por $\mathrm{mm}, 150-200 \mu$ de diâmetro.

dissepimento : (Est.XXI, fig.c) de espessura mais ou menos uniforme, variando de $40-120 \mu$; formado por hifas semelhantes às do contexto, prevalecendo as de menor diâmetro.

HIMENIO : (Est. XXI)

cistídias e setas, não existentes.

medas : (fig. d) poucas, cilíndricas, $12-20 \mu$ de diâmetro, ultrapassando. as basídias em 10-15 $\mu$.

basídias : (fig. e) subglobosas, hialinas, 6-8 $\mu$ de diâmetro por $10-12 \mu$. longas.

esporos : (fig. f) muito ligeiramente citrinos, multi-gutulados, cilíndrico-elipsóides, 3-4 × 5-6u.

Observações : Descrição baseada no Material n. ${ }^{\circ} 4868$ do Herb. Mic. da Seção de Botânica, I. A., Campinas, Est. S. Paulo.

Trametes caperata Berkeley (Est. XXII, XXIII)

PILEO : (Est. XXII) efuso-reflexo, raro séssil, dimidiado; parte reflexa $2-4 \times 3-5 \mathrm{~cm}$, por $2-4 \mathrm{~mm}$ espêssa.

superfície : (Est. XXII, fig. a) tomentosa, com pêlos castanhoescuros a amarelados; concêntricamente sulcada, com 1-2 sulcos por cm ; nos sulcos, e em zonas glabras, concêntricas, percebese uma superficie castanho-vinosa, radial e minutamente estriada, muito caraterística.

margem : (Est. XXII, fig. b) inteira ; quando em pileos anastomosados, apresenta-se lobada; de bordos geralmente glabros, às vêzes velutinos, lisos a minutamente franzidos; subaguda a. aguda, estéril em baixo.

CONTEXTO : (Est. XXIII, fig. c) castanho-claro, homogêneo, 1-2mm espêsso ; muitas vêzes nulo.

hifas do contexto : (Est. XXIII, fig. a) castanhas, não reagem em $\mathrm{KOH}$; lisas a suavemente sinuosas, variam de $2-4 \mu$ de diâmetro ; de parede estreita e largo lúmen, não apresentam nem septos. nem ramificações (apenas as de $2 \mu$ de diâm. são pouco ramificadas).

TUBOS : (Est. XXIII, fig. b) amarelados, mais claros que o contexto, 0,5-1,5mm longos.

poros : (Est. XXII, fig. c ; XXIII, fig. b) de superfície castanhoamarelada bem clara, sendo mesmo esbranquiçada em espécimés: 
em pleno desenvolvimento ; circulares a angulares, $3-4$ por $\mathrm{mm}$, de bordos lisos.

dissepimento : (Est. XXIII, fig. c) de espessura homogênea, variando de 70 a $120 \mu$; formado por hifas semelhantes ds do contexto, porém mais finas, de $2-3 \mu$ de diâmetro.

\section{HIMENIO : (Est. XXIII)}

cistídias e setas, inexistentes

basidias : (fig. d) hialinas, clavadas, 3,5-10 $\mu$.

medas : (fig. e) abundantíssimas, cilíndrico-cônicas, projetando-se além das basídias de $30-40 \mu$.

esporos : (fig. f) hialinos, lisos, cilíndricos; $2 \times 6 \mu$, na média.

Observações : Diagnose baseada no material n. 862 do Herb. Mic. da Secção de Botânica, I. A., Campinas, Est. S. Paulo.

\section{$* * *$ \\ G L O S S $\AA$ A R I O}

(Est. XXIV, XXV, XXVI)

BASIDIAS : são estruturas sexugis sôbre as quais são produzidos os esporos dos basidiomicetos. Quando septadas ou profundamente sulcadas, são chamadas heterobasidias, e caraterizam os Heterobasidiomicetos (fig. 33 a 37). Quando não septadas, e típicamente clavadas (fig. 38 a 40), são chamadas homobasidias, e caraterizam os Homobasidiomicetos. Como as poliporáceas pertencem a êste último grupo, vejamos quais as formas em que podem apresentar-se as homobasidias :

clavadas - fig. 38

subglobosas - fig. 39

subcilíndricas - fig. 40

BASIDIOSPOROS : assim são chamados os esporos produzidos por basídias. Podem ser septados ou não, ao germinar. Nas poliporáceas, porém, nunca se tornam septados. Quanto aos caraterísticos gerais, os esporos das poliporáceas podem ser:

lisos - fig. 43 a 49

tuberculados - fig. 41

espinulados - fig. 42

de parede espêssa - fig. 43

de parede imperceptivel - fig. 45

hialinos - sem pigmentação - fig. 45 a 49

coloridos - com pigmentação - fig. 43 e 44

globosos - fig. 42

subglobusos - fig. 43

ooóides - fig. 44

elipsoides - fig. 46

cilindrico-elipsoides - fig. 45

cilindricos - fig. 47

alantoides - fig. 48

reniformes - fig. 49

de Ganoderma - fig. 50

CISTIDLAS = órgāos semelhantes às basídias, porém estéreis, e mais avantrjados que estas. Nas poliporáceas localizam-8e sempre no himênio, ao passo que em outros 
himenomicetos podem localizar-se fora dêle. As cistídias das poliporáceas podem ser :

cilindricas - fig. 51

cilindrico-ventricosas - fig. 52

clavadas - fig. 53

globosas - fig. 54

lankeoladas - fig. 56

capitadas - fig. 55

lisas - fig. 51, 52, 53, 54 e 56.

CONTEXTO : dá-se êste nome à trama de hifas que constitui o corpo de frutificação dos himenomicetos; excetuam-se aqui a camada himenial e a crosta glabra ou pilosa da superfície. A parte do contexto que forma a parede dos tubos chama-se dissepimento.

quanto à consistência :

frouxxa - quando cede fàcilmente à pressão de nossos dedos.

carnoso-mole - quando se assemelha àquela das agaricáceas em geral, i.é, quando é aquosa, fàcilmente esmagável à mão.

coriacea - flexível, semelhante a couro.

suberosa - semelhante a cortiça

lenhosa - semelhante a madeira

quanto à coloração : variando grandemente quanto à côr, o contexto pode ser : branco; esbranquiçado ; rosado; castanho-claro; castanho-escuro ; ferrugineo; homogéneo, i.é, quando a coloraçăo é de tonalidade uniforme ; zoñado, i.é, quando hé zonas, verdadeiras camadas, geralmente concêntricas, de tonalidades diferentes.

quanto às hifas : as hifas que constituem a trama do contexto variam muito quanto à forma, coloraçäo, ramificação, septação, etc., e podem ser :

hialinjas - fig. 57, 63 e 64

coloridas - fig. $58,59,60,61$ e 62

de paredes grossas - fig. 61

de paredes finas - fig. 60 e 62

pouco ramificadas - fig. 59 e 62

muito ramificadas - fig. 63

não septadas - fig. 60

septadas - fig. 62

ganchos de ligação presentes - fig. 64

CORPO-DE-FRUTIFICAÇÃO : é o esporóforo dos himenomicetos. Nas poliporáceas pode ser :

ressupinado - quando cresce esparramado sôbre o substrato - fig. 12

efuso-reflexo - quando, tendo parte ressupinada, levanta-se do substrato para formar o píleo - fig. 13

séssil - quando se prende lateralmente ao substrato, sem que qualquer de suas partes se mostre ressupinada - fig. $6,7,8,10,11,14,16,18,19$ e 20

estipitado - quando o píleo se prende ao substrato por meio de um estipe ou "cabo"

- fig. $1,2,3,4,5,9,17$ e 22

DISSEPIMENTO : dá-se êste nome àquela trama de hifas que liga intimamente um tubo ao outro, nas poliporáceas. E a propria parede dos tubos - fig. 21 a, 23 a, 24 a.

ESPORÓFORO : dá-se êste nome à estrutura, de qualquer fungo, produtora dos esporos sexuais. Nos himenomicetos ê também chamado corpo-de-frutificação.

ESTERIGMAS : são os finos prolongamentos que, partindo das basídias, produzem os esporos na extremidade, sustentando-os alí até sua maturação. As basídias das poliporáceas possuem quatro esterigmas - fig. 38 a, 39 a, 40 a. 


\section{ESTIPE :}

quanto à colocação :

central - fig. 1 b, 3 b, 9 b, 17 a.

dorsal - fig. 2 b.

excêntrico - fig. 5 b.

lateral - fig. 4 a, 22 a.

quanto ao formato :

curto - fig. 4 a, 5 a, 22 a.

longo - fig. $1 \mathrm{~b}, 2 \mathrm{~b}, 3 \mathrm{~b}, 9 \mathrm{a}, 17 \mathrm{a}$.

cilíndrico - fig. $1 \mathrm{~b}, 3 \mathrm{~b}$.

cônico - fig. 9 a.

obcônico - fig. 5 a, 17 a.

direito - fig. $1 \mathrm{~b}, 3 \mathrm{~b}$.

sinuoso - fig. $2 \mathrm{~b}$.

simples - fig. (tôdas, com exceção da 2 b)

ramificado - fig. 2 b.

quanto à superficie :

pilosa - quando coberta por pêlos, fig. 5 a.

glabra - sem pêlos

escabrosa - grosseiramente áspera, fig. 2 a.

estriada - com delicadas estrias longitudinais.

lacada - quando possui uma camada como que de verniz, pouco ou muito brilhante.

lisa - sem qualquer acidente.

GANCHOS-DE-LIGACÃO : em determinadas hifas dos basidiomicetos notam-se pequenas protuberâncias, semicirculares, ôcas, lateralmente ligadas às paredes de duas células adjacentes, e localizadas exatamente sôbre os septos que separam tais células. Estés protuberâncias, resultantes da união sexual entre aquelas células vegetativas, são os ganchos-de-ligação, também chamados alças pelos autores portuguêses, e clamp-connections em inglês. Ver fig. 64 .

\section{HETEROBASIDIAS : ver basídias.}

HIMENIO : as basídias podem crescer desordenadamente, como nos Hemibasidiomticetos, ou podem crescer agregadas, lado a lado, tôdas aproximadamente a uma s6 altura, formando uma camada contínua, uniforme ; a essa camada de basídias dá-se o nome de himênia. o que acontece com os Himenomicetos e Gasteromicetos.

HIMENOFORO : corresponde a esporoforo e a corpo-de-frutificagåo, nos himenomicetos.

\section{HOMOBASIDIAS : ver basidias.}

LUMEN : nome dado à cavidade, espaço vasio, dos tubos, hifas, etc. - fig. 60 a, 62 b.

MEDAS : são grandes feixes de delicadas hifas que atravessam o himénio e se projetam no lúmen dos tubos. São encontradas nos himenomicetos e, com mais frequência, nas poliporáceas. Variam quanto a forma, e podem ser :

cillndrico-globosas - fig. 30

cillndrico-cónicas - fig. 31 a

cóntcas - fig. $31 \mathrm{~b}$

PARAFISES : dáne éste nome a hifas estéreis que, no himênio das poliporáceas, muitas vêzes aparecem igualando as basídias em altura, outras véres as ultrapassando do muito. Podem ser :

simples - fig. 32 a, b, d.

ramificadas - fig. 32 c.

clavadas - fig. 32 b.

cilindricas - fig. 32 d.

filiformes - fig. 32 a. 
PfLEO : e a parte não ressupinada do corpo de frutificação dos himenomicetos, que apresenta a camada himenial, ou os poros (no caso das poliporaceas).

quanto ao estipe :

curto-estipitado - fig. 4, 5, 22.

longo-estipitado - fig. 1, 2, 3, 9, 17.

mes6podo - com estipe central - fig. 1, 3, 9, 17.

pleuropodo - com estipe lateral - fig. 4, 22.

de estipe excêtitrico - fig. 5.

do estipe dorsal - fig. 2.

quanto à margem : a margem do plleo varia muito, e pode ser:

aguda - fig. $1 \mathrm{~d}$.

subaguda - fig. 5 c.

obtusa - fig. $3 \mathrm{~d}$.

lisa - fig. $1 \mathrm{~d}$.

ondulada - fig. $9 \mathrm{~b}, 18 \mathrm{~b}$.

lobada - fig. 5 c.

inteira - fig. $1 \mathrm{~d}$.

fendida - fig. 5 c.

fértil em baixo - quando há poros até junto aos bordos.

estéril em baixo - quando há uma estreita faixa, junto aos bordos, sem poros.

quanto à forma : visto do alto, o ṕleo apresenta as mais variadas formas, e se classifica em :

dimidiado - fig. 8

flabeliforme - fig. 7

petalbide - fig. 6

espatulado - fig. 4

reniforme - fig. 2

circular - fig. $1,3,9,17$

irregular - fig. 5

quanto ao perfil :

convexo - fig. 17

deprimido 一 fig. 3

umbonado - fig. 9

infundibuliformie - fig. 1,5

aplanado - fig. 10, 16

conchado - fig. 14

ungulado - fig. 11

imbricado - fig. 15

quanto à superfície : os caraterísticos apresentados pela superfície do píleo muito auxiliam na classificação e distinção das espécies. Segundo o seu aspecto geral, a superficie pode ser :

glabra - sem pêlos

estrigosa - com pêlos longos, mas muito ralos, podendo-se avistar a superfície glabra em baixo.

flocosa - quando os pêlos se apresentam agrupados em feixes.

hirsuta - com pêlos duros, ásperos ao tato.

puberulenta - com pêlos muito curtos, mas ainda visíveis a ôlho nu.

pubescente - com pêlos só visíveis com o auxílio de uma lupa.

tomentosa - com pêlos longos e emaranhados.

velutina - semelhante a veludo.

lacada - coberta como que por uma camada de verniz.

rimosa - tôda fendilhada em pequenas fendas irregulares.

sulcada - com profundas depressões concêntricas.

zonada - com faixas concêntricas diferenciadas na côr.

estriada - com delicadas nervuras geralmente radiais.

escabrosa - muito grosseiramente áspera.

lisa - sem qualquer acidente. 
:POROS : dá-se êste nome às bôcas dos tubos.

quanto ao formato:

$$
\begin{aligned}
& \text { circulares - fig. } 20,23 \\
& \text { alongados - fig. } 24 \\
& \text { hexagonais - fig. } 21 \\
& \text { "ongo hexagonais - fig. } 22 \\
& \text { dedalóides - fig. } 19 \\
& \text { concêntricamerọte lamelares - fig. } 17 \\
& \text { radialmente lamelares - fig. } 18
\end{aligned}
$$

quanto aos bordos : os bordos dos poros variam muito quanto à sua constituição, e podem ser :

lisos - fig. 25

dentados a serrithados - fig. 26

fimbriados - fig. 27

lacerados - fig. 28

'SETAS : como as cistídias, são órgãos estéreis que aparecem no himênio. Geralmente são profundamente coloridas, denegridas. No geral, são pontudas, semelhantes a pequenos espinhos. Podem ser :

ventricosas - fig. 29 a.

subuladas - fig. 29 b.

direitas - fig. 29 a, b.

curvas - fig. $29 \mathrm{c}$.

SLBSTRATO : é a matéria sôbre a qual vive o fungo. No caso das poliporáceas, geralmente se trata de madeira.

TRAMA : dá-se êste nome ao entretecido de hifas que formam o corpo de frutificação. Assim é que dizemos: trama do contexto, trama do dissepimento, etc.

TUBOS : são as perfuraçōes encontradas no corpo de frutificação dus poliporáceas, boletáceas, fjstulináceas e meruliácetas, na parede das quais cresce o himênio. As bốcas dos tuibos recébem o nome de poros.

\section{'PKINCIPAL LITERATURA CONSULTADA}

1. Ainsworth, G. C. e G. R. Bisby. Em A Dictionary of the Fungi, pgs. 1-339. fig. 1-138. The Imperial Mycological Institute, Kew, Surrey, 1943.

2. Bessey, E. A. Em A Text-Book of Mycology, pgs. 1-495. ilustrado. P. Blakiston's Son \& Con., Inc. Phyladelphia, 1935.

3. Bourdot, H. e A. Galzin. Em Hyménomycètes de France, pgs. 1-761. Sceaux, 1927.

4. Gaeumann, E. A. e'C. W. Dodge $E m$ Comparative morphology of fungi, pgs. 1-701. '1.a edição, ilustrada, McGraw-Hill Book Company, Inc. N. Y., 1928.

5- Killermann, S. Rèihe Hymenomycetese. Em Engler, A. e K. Prantl. Natuerlichen Pflanzenfamilien 6 : 99-283. Leipzig, 1928.

6. Lloyd, C. G. Em Mycological Notes 1 : a 7 : pgs. 1-1348, fig. 1-3266. Cincinnati, Ohio, U.S.A., 1898-1922.

7. Lowe, J. L. The Polyporacea of New York State (Pileate Species). Tech. Bul. of the.N. 'Y.'Sta. College of Forestry at Syrac. Univ. 41 : 1-142. ill. 1934.

8. Moeller, A. $\boldsymbol{E} m$ Protobasidiomyceten, untersuchungen aus Brasilien. I-XI+ 1-179. taif. 1-6. Jena, 1895.

9. Overholts, L. O. Comparative studies in the Polyporaceae. Sep. Annals Mo. Bot. Garden 2:: 667-730. ill. 1915. 
10. Overholts, L. O. Research Methods in the Taxonomy of the Hymenomycetes. Sep. Proceedings of the International Congress of Plant Sciences 2 : 16881712 , ill., 1929.

11. Overholts, L. O. The Polyporaceae of Pennsylvania I. (The genus Polyporus). Tech. Bul. The Penn. Sta. College 298: 1-28. pl. 1-2. 1933.

12. Overholts, L. O. The Polyporaceae of Pennsylvania II. (The genera Cyclomyces, Daedalea, Favolus, Fomes, Lenzites and Trametes). Tech. Bul. The Penn. Sta. College 316: 1-16. pl. 1-2. 1935.

13. Viégas, A. P. Técnica de cortes à mão livre. Bragantia 3 : 193-198. est. 1, Instituto Agronômico, Campinas, 1943.

14. Wettstein, Dr. Richard. Em Handbuch der Systematichen Botanik, pgs.. 1-1 149, ilustrado, Franz Deuticke, Leipzig, 1935. 
Est. I
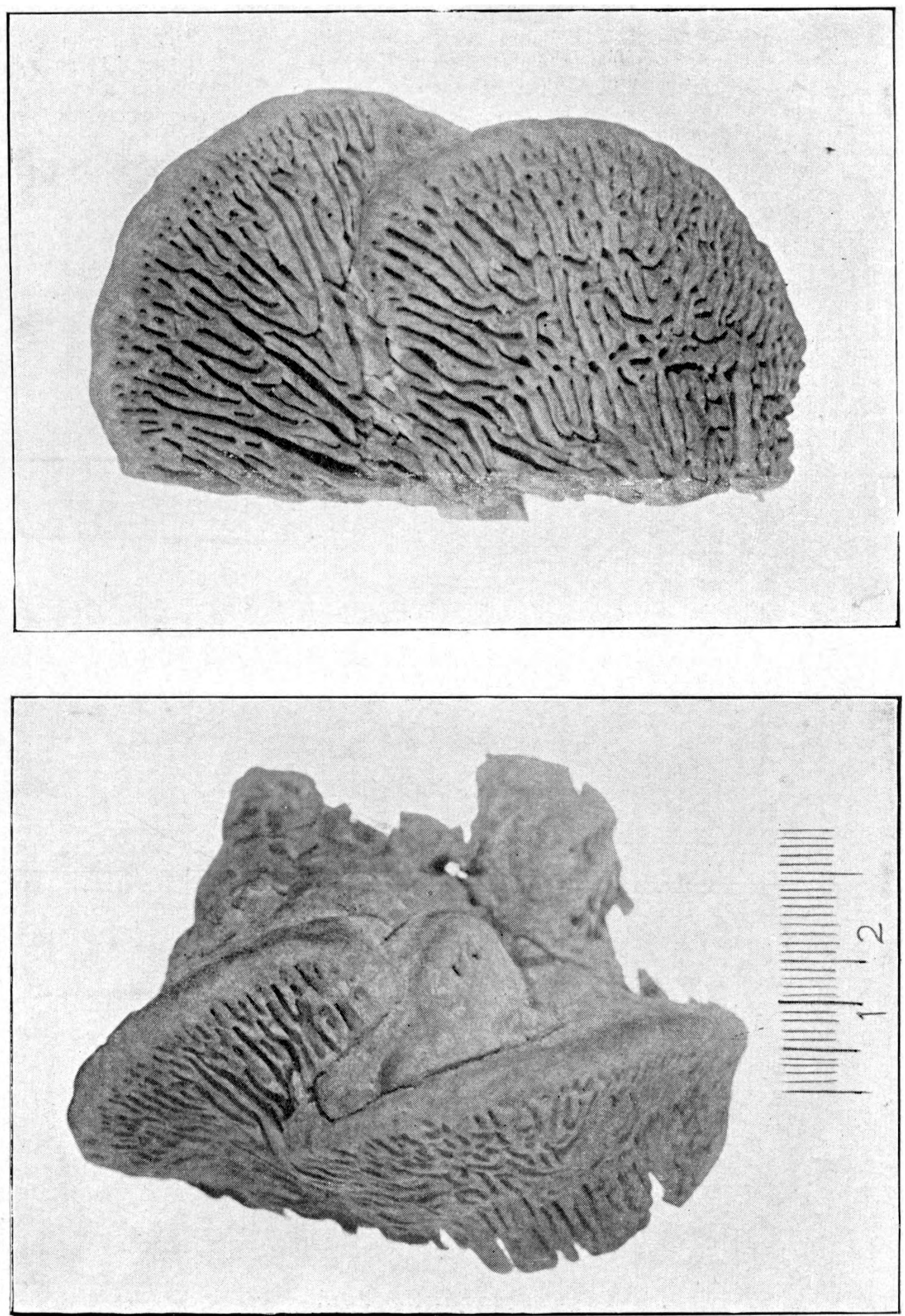

Daedalea auercina (L.) Fries. 
D $0^{b} o$<smiles>CC(=O)C1CCCCC1</smiles>
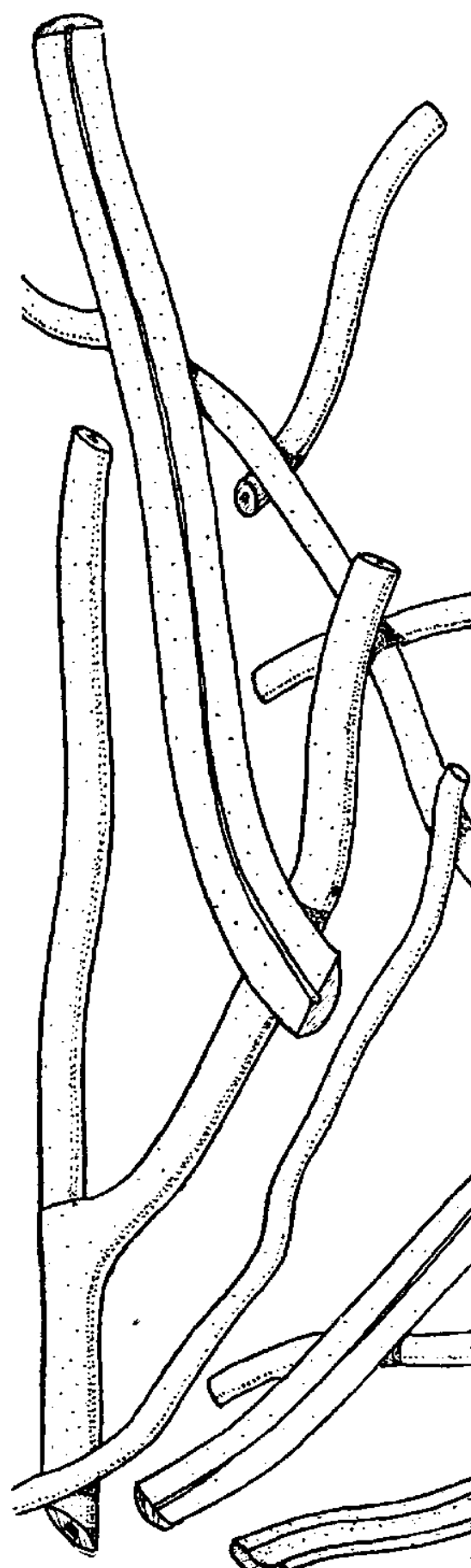
Est. III

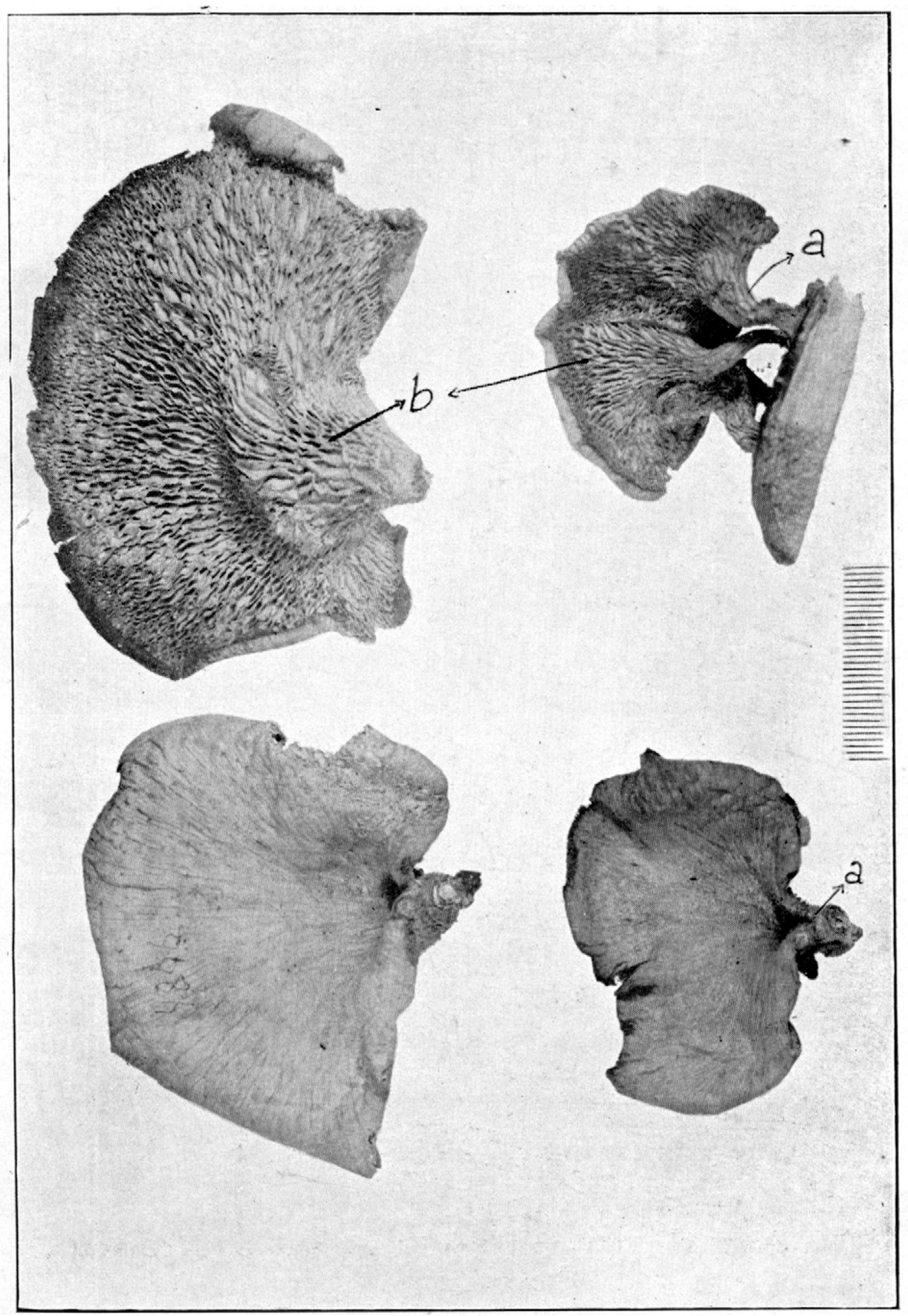

Favolus brasiliensis Frica 

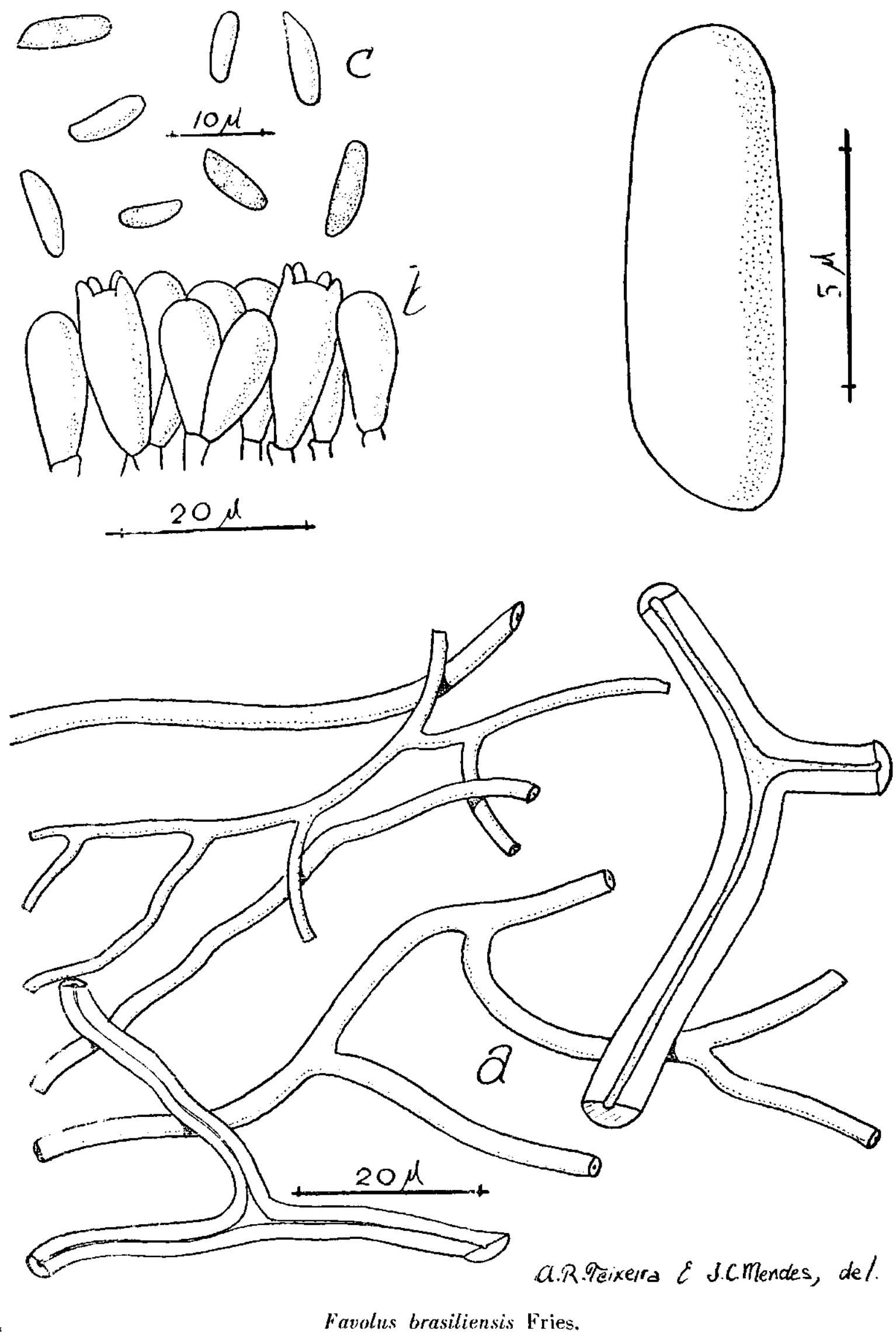
Est. V

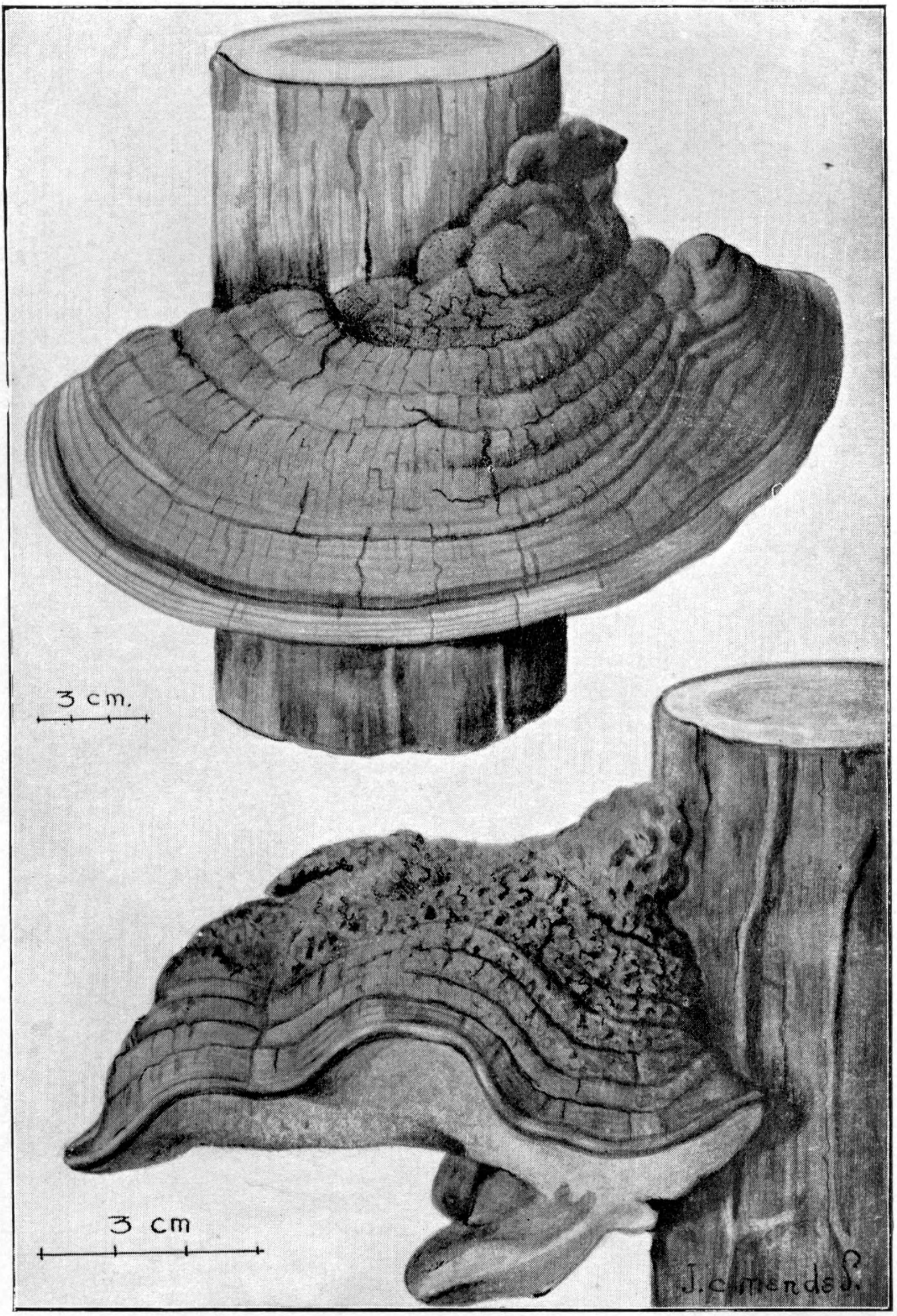

Fomes rimosus (Berk.) Conke 


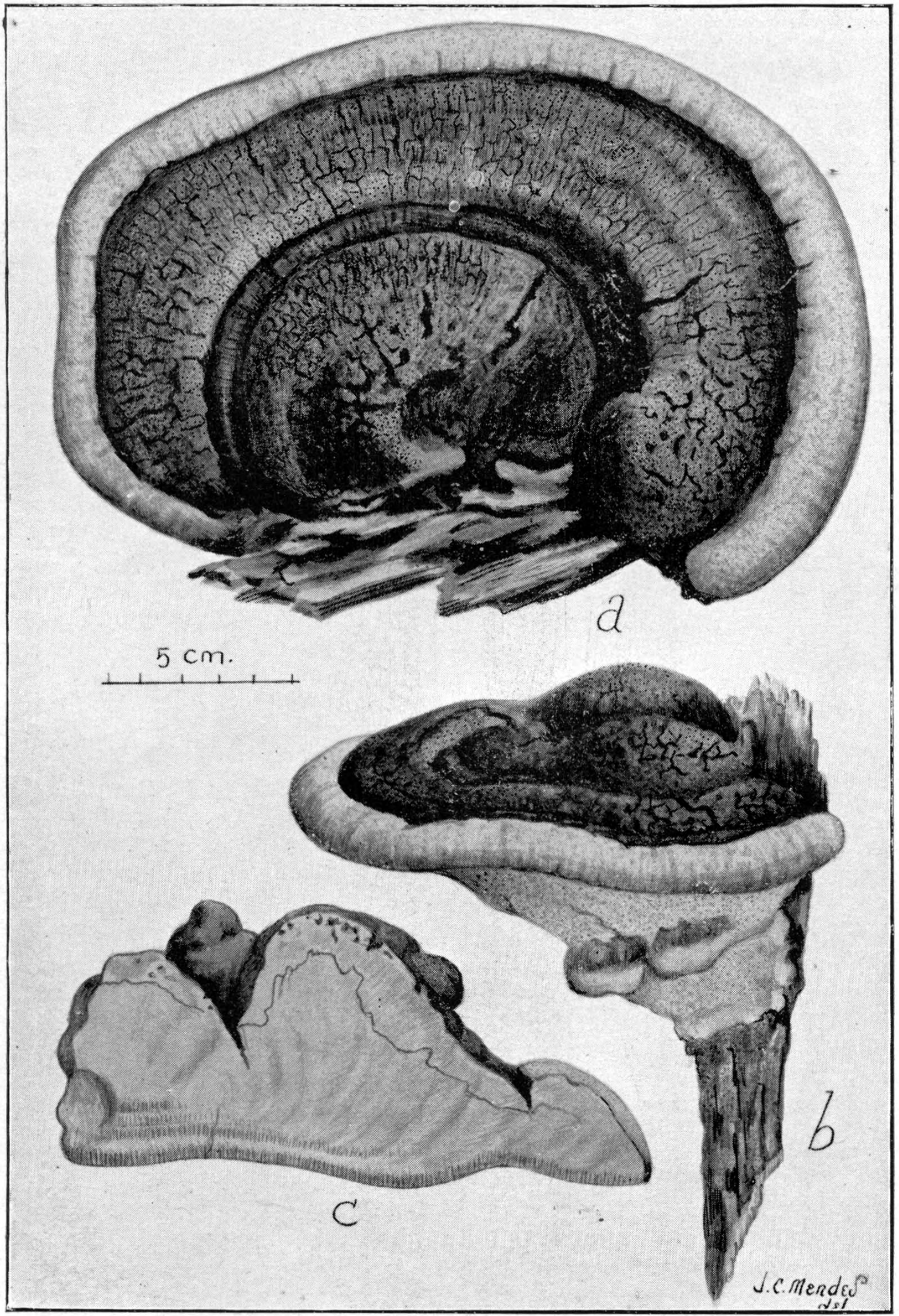


Est. VII
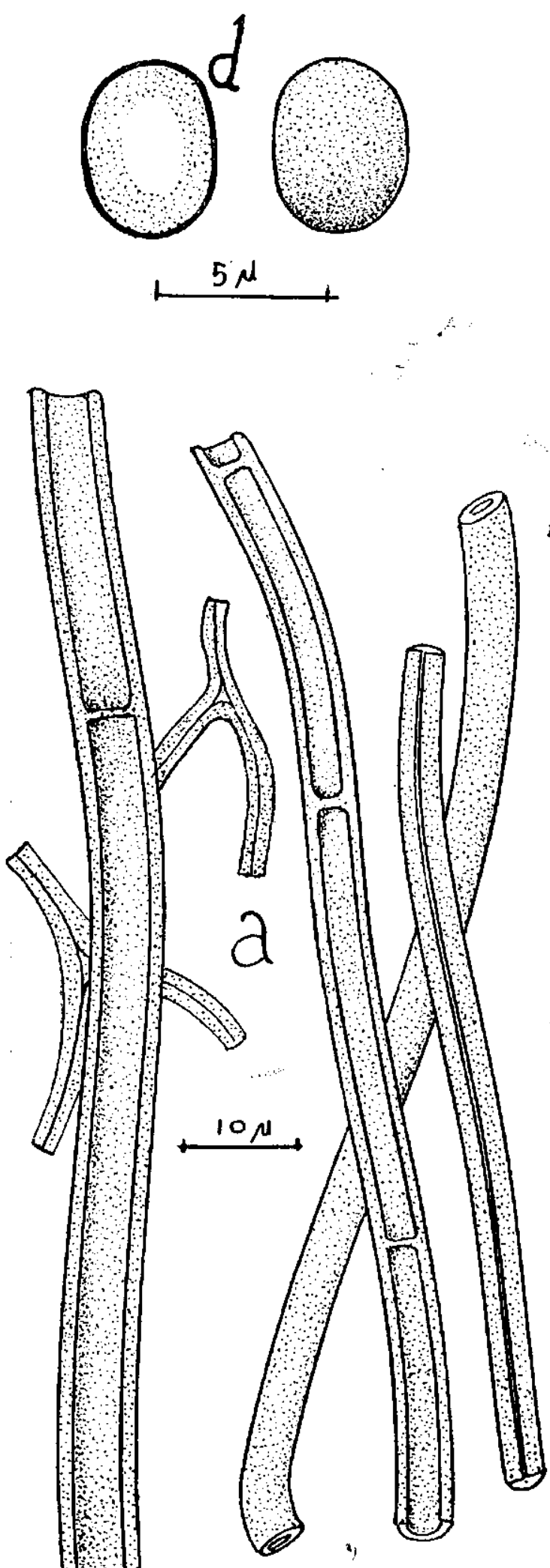

a R.Teixerra e J.C.Mendes, del.
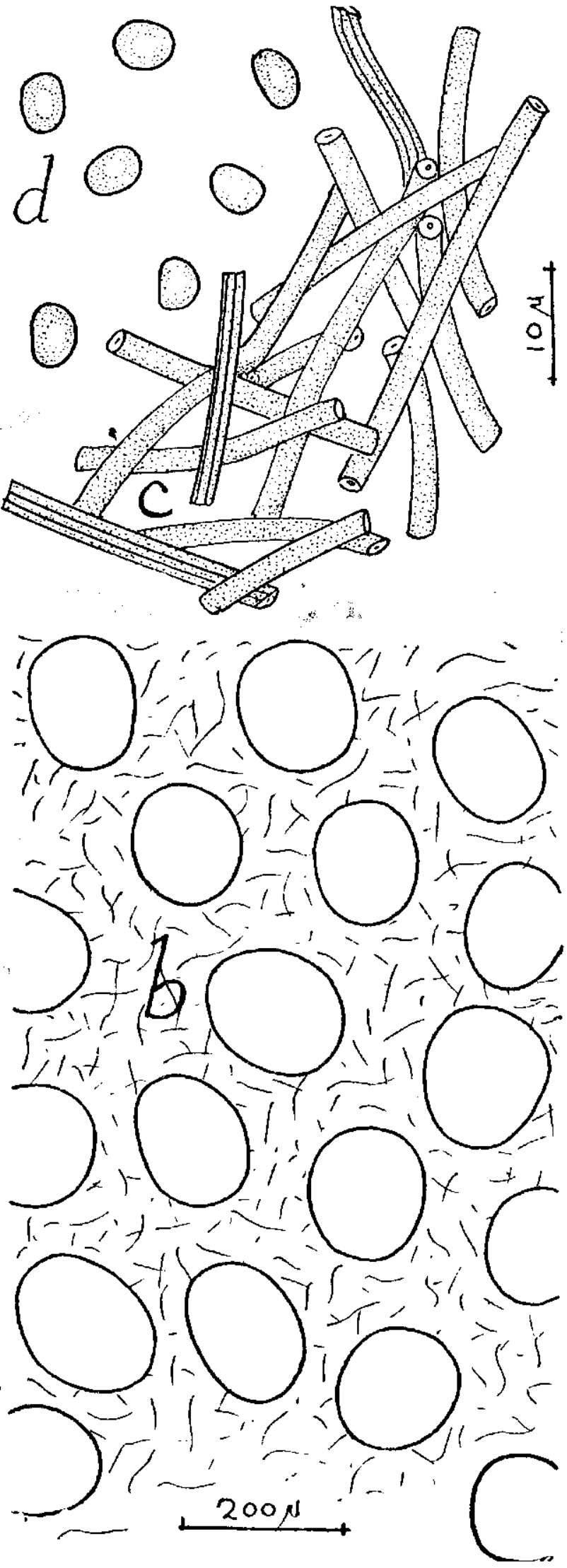

Fomes rimosus (Berk.) Cooke 
Est. VII [

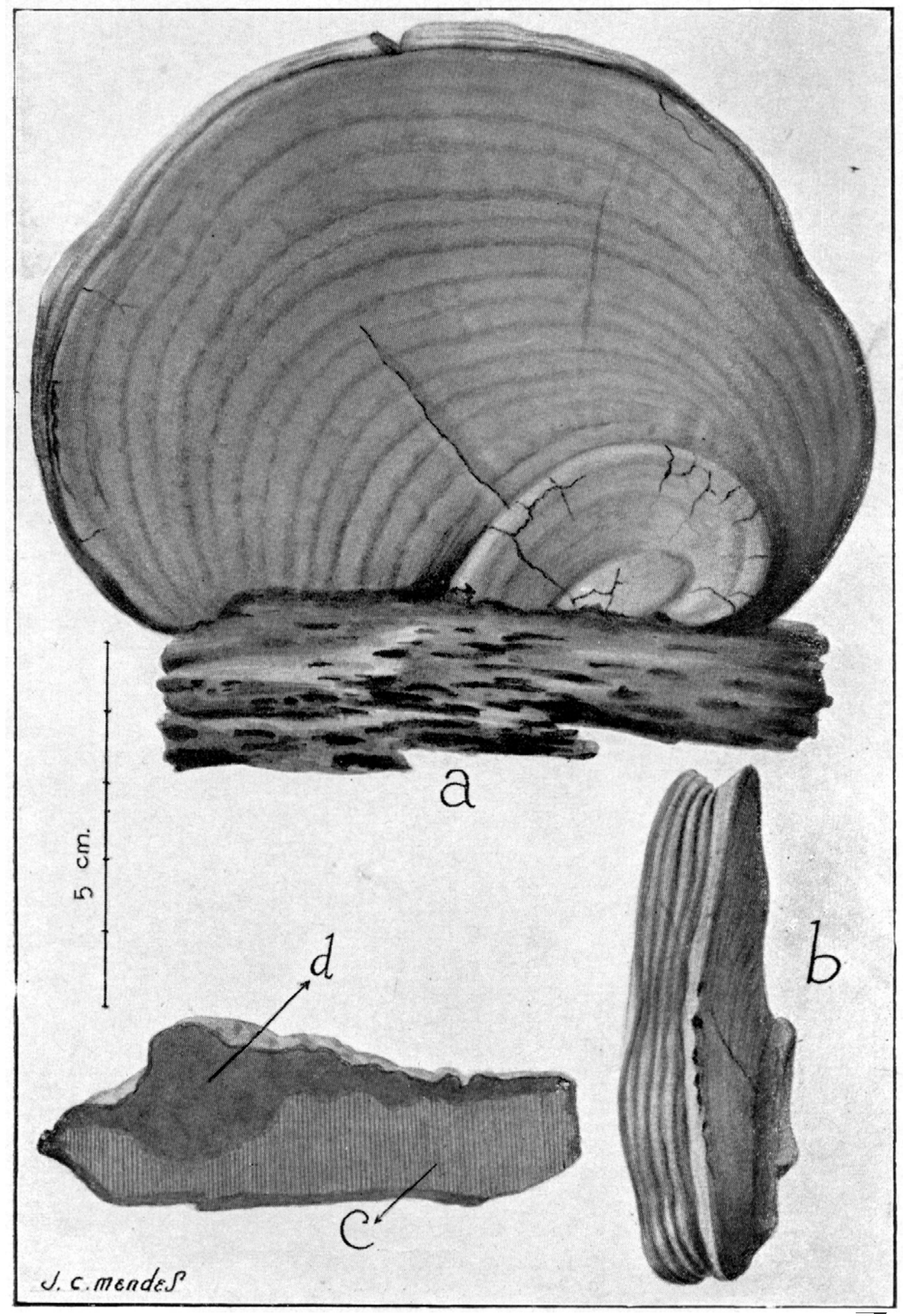

Ganoderma applanatum (Pers.) Pat. 
Est. $1 \mathrm{X}$
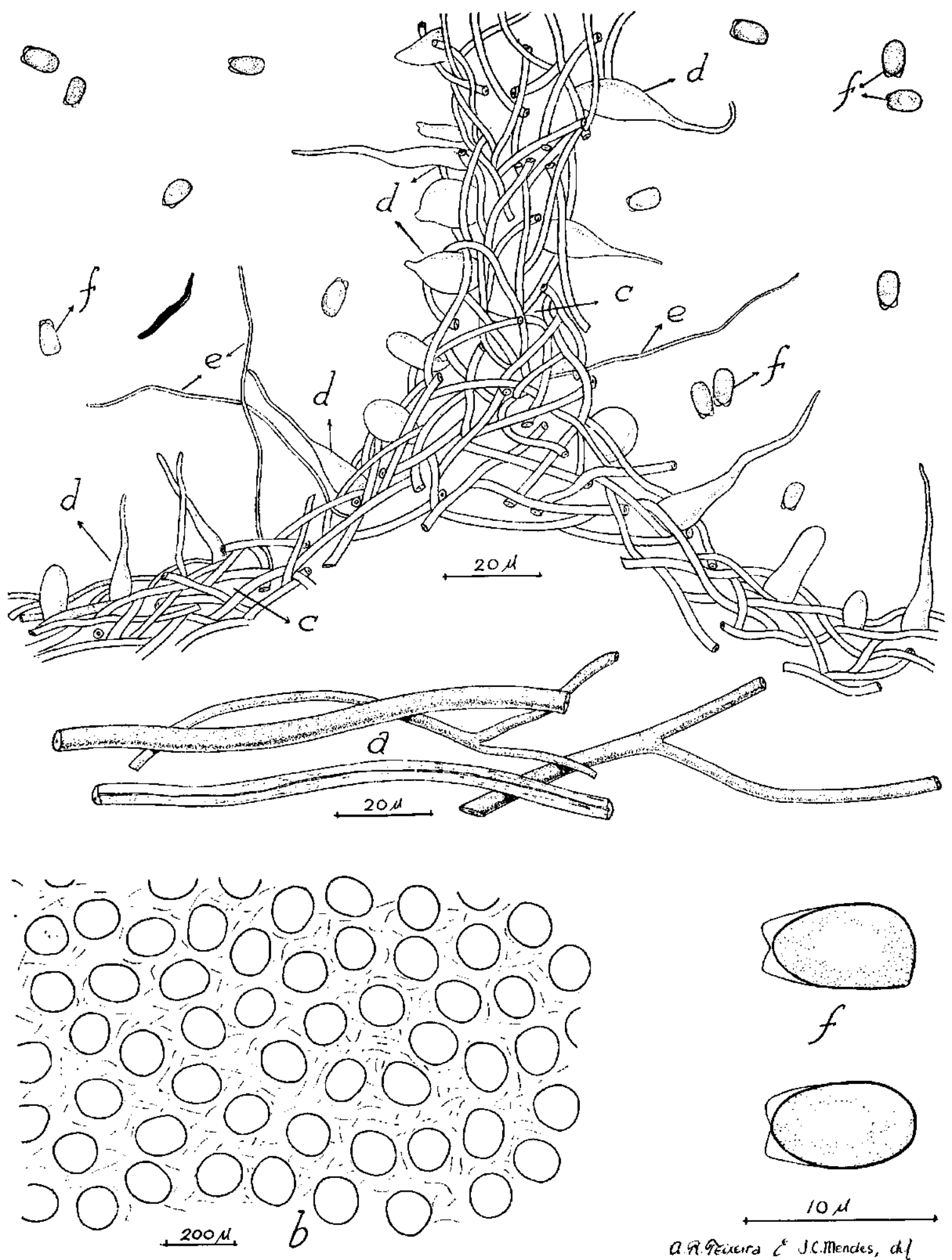

Ganoderma applanatum (Pers.) Pat. 
Est. X

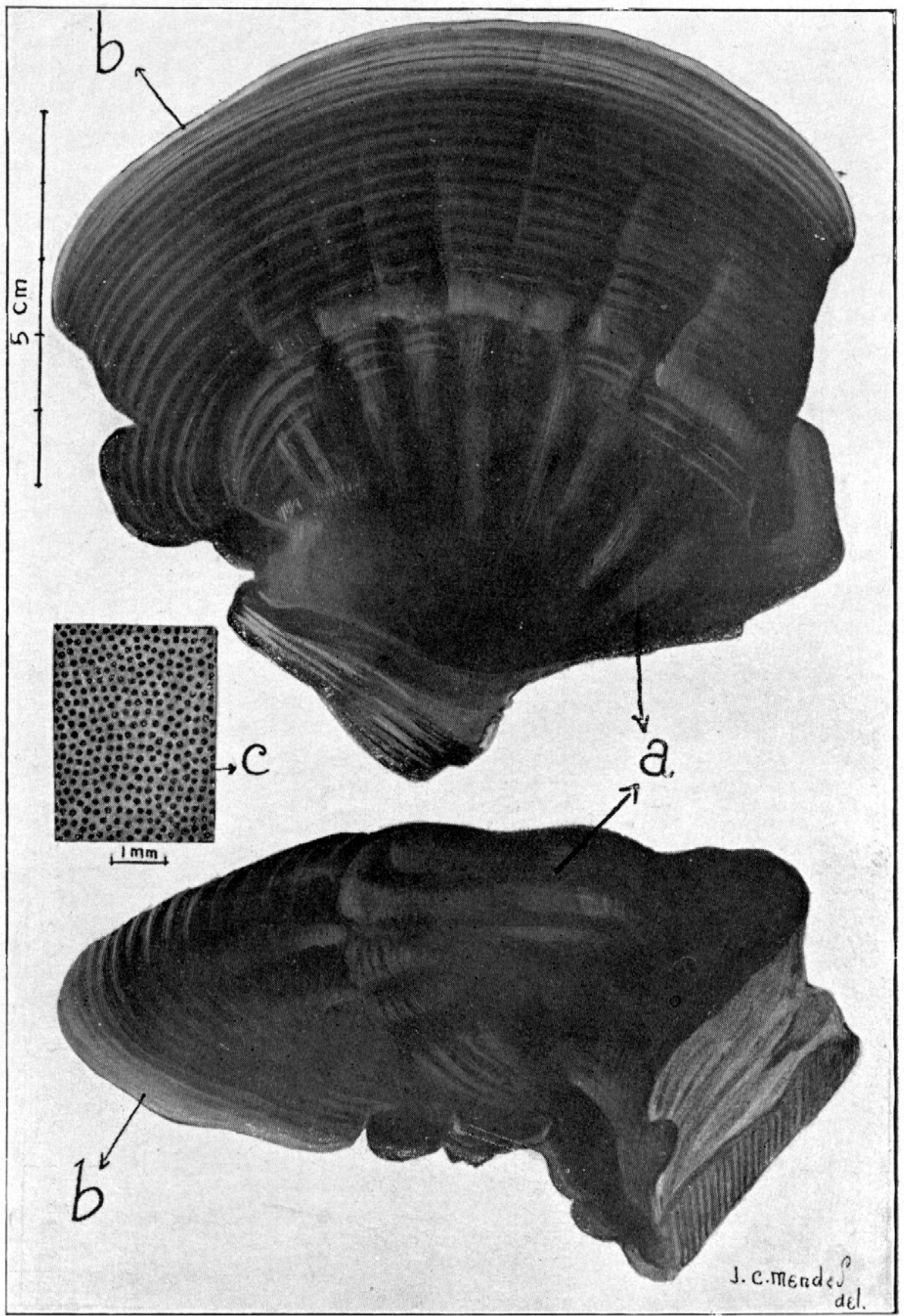

Ganoderma sp. (laccalum Kalchb.?) 
Est. XI
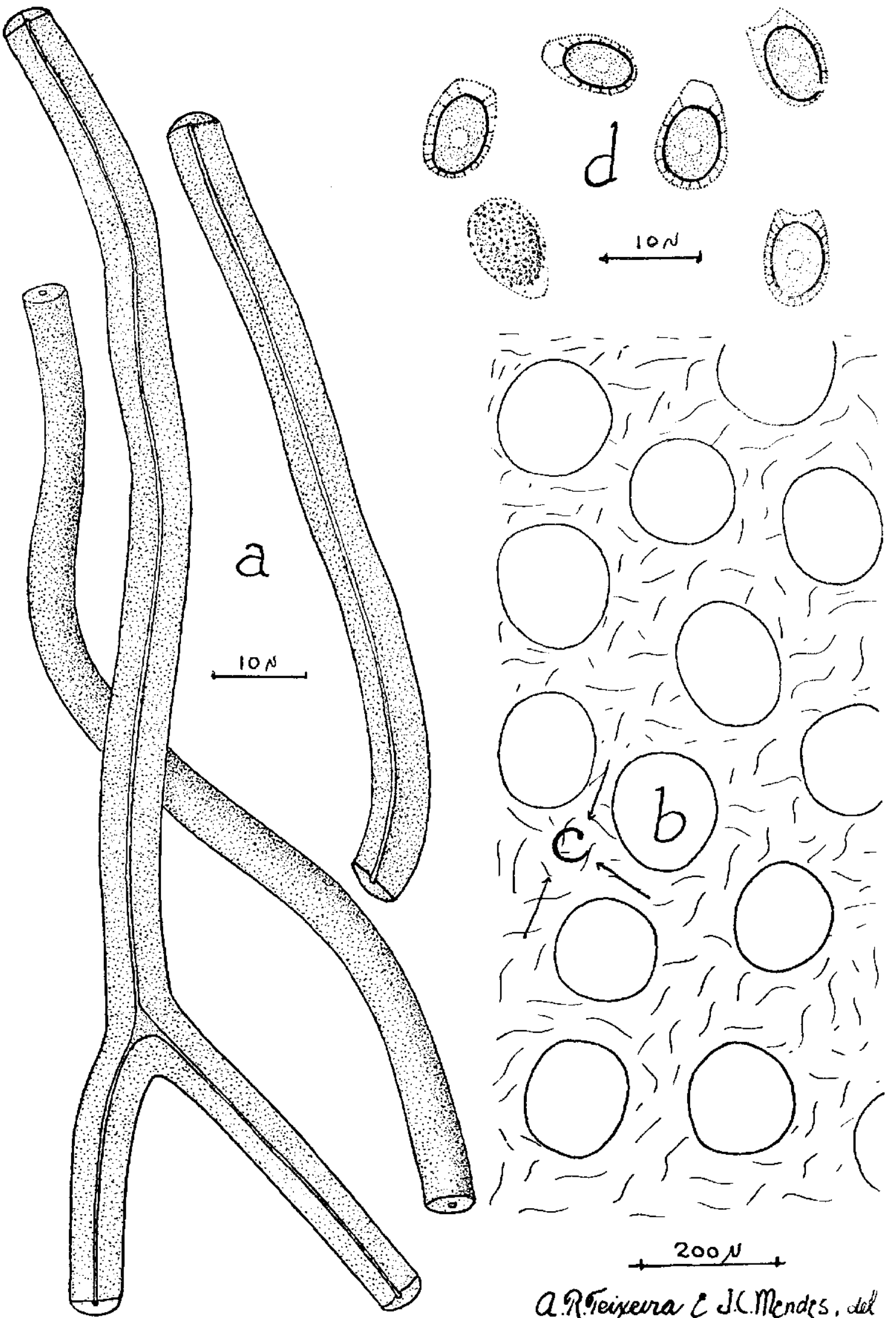

a.Treixerara \& J.C.Mendes, del

Ganoderma sp. (Laccatum Kalchb.?) 


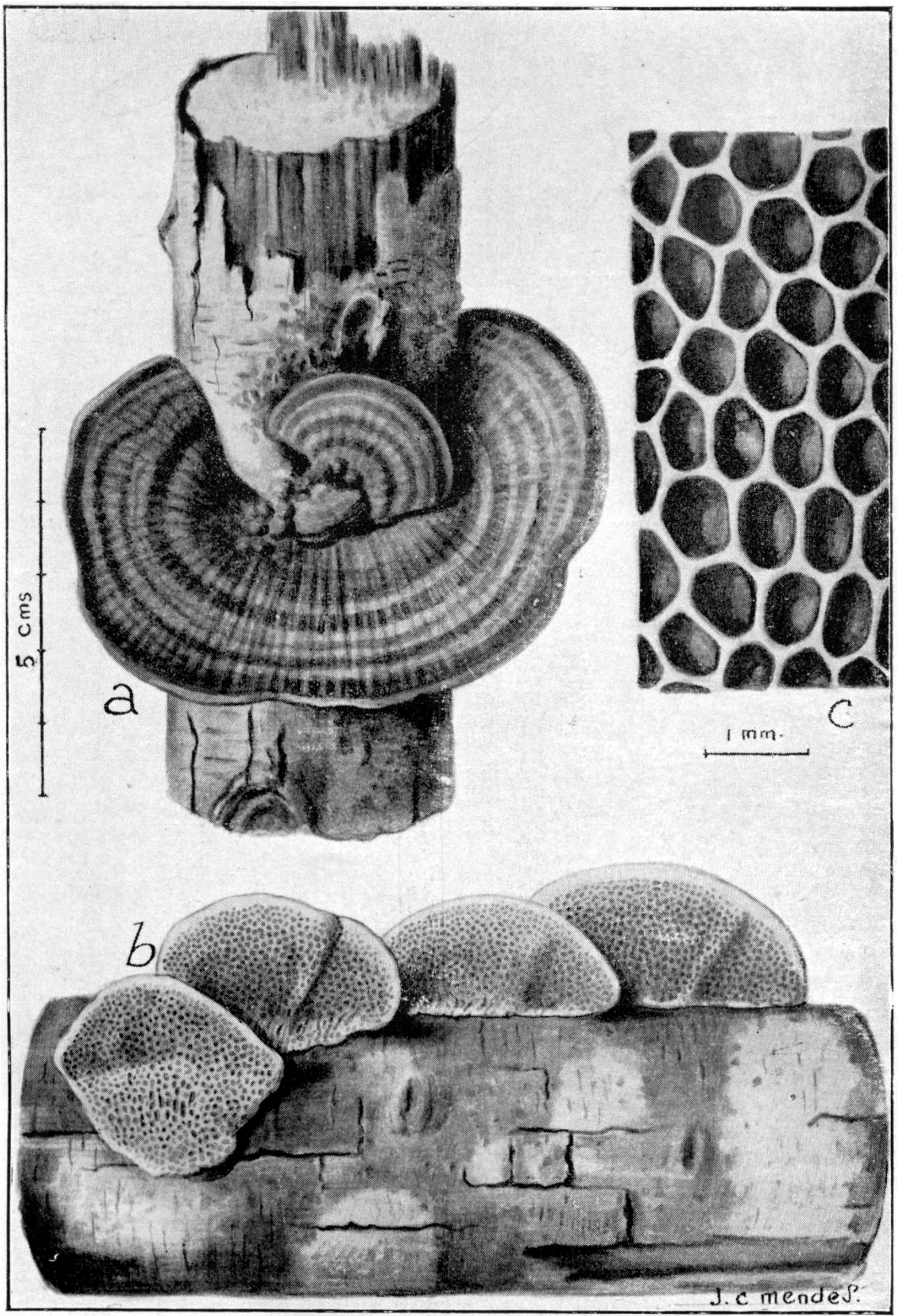


Est. XIII
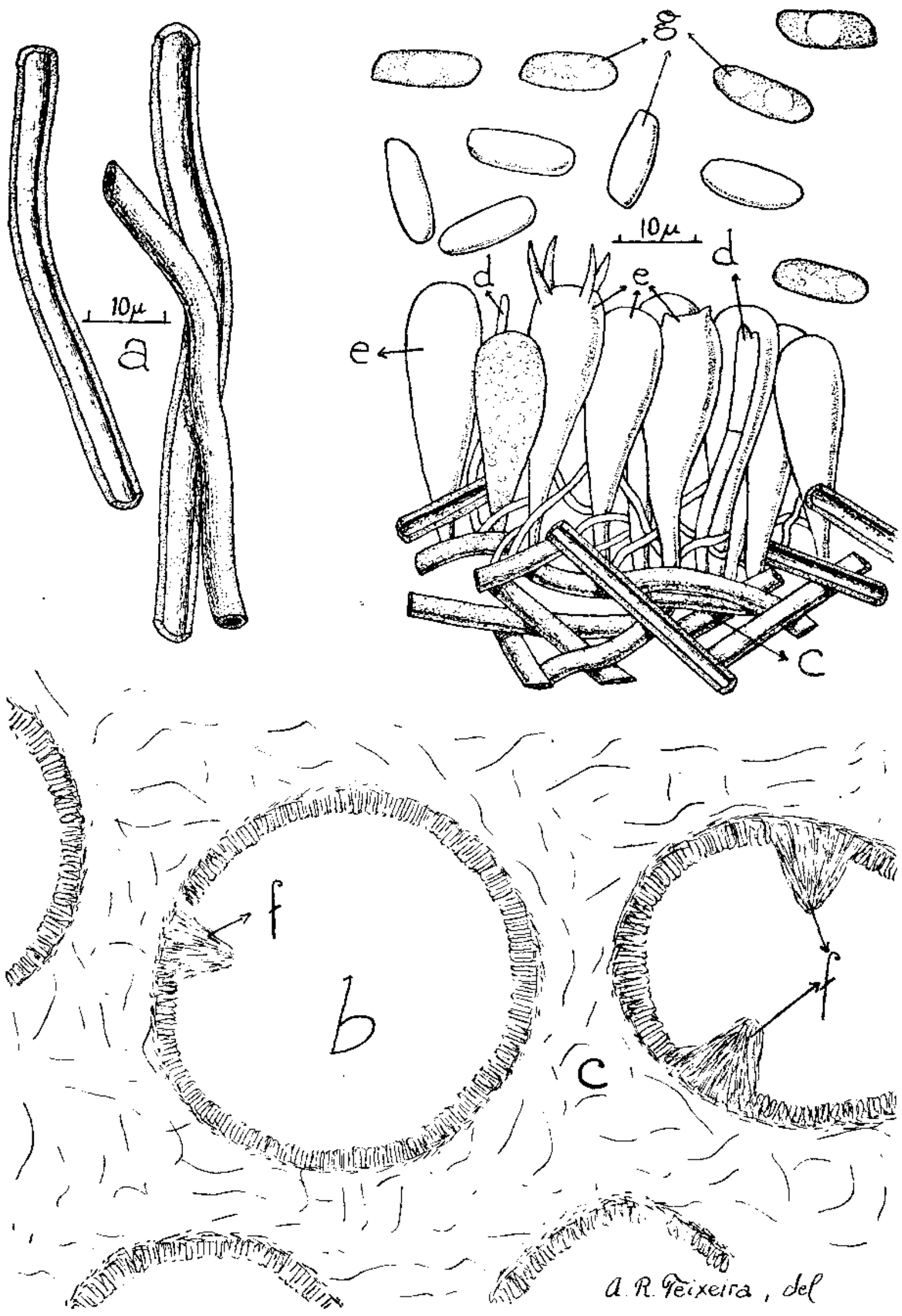
Est. XIV

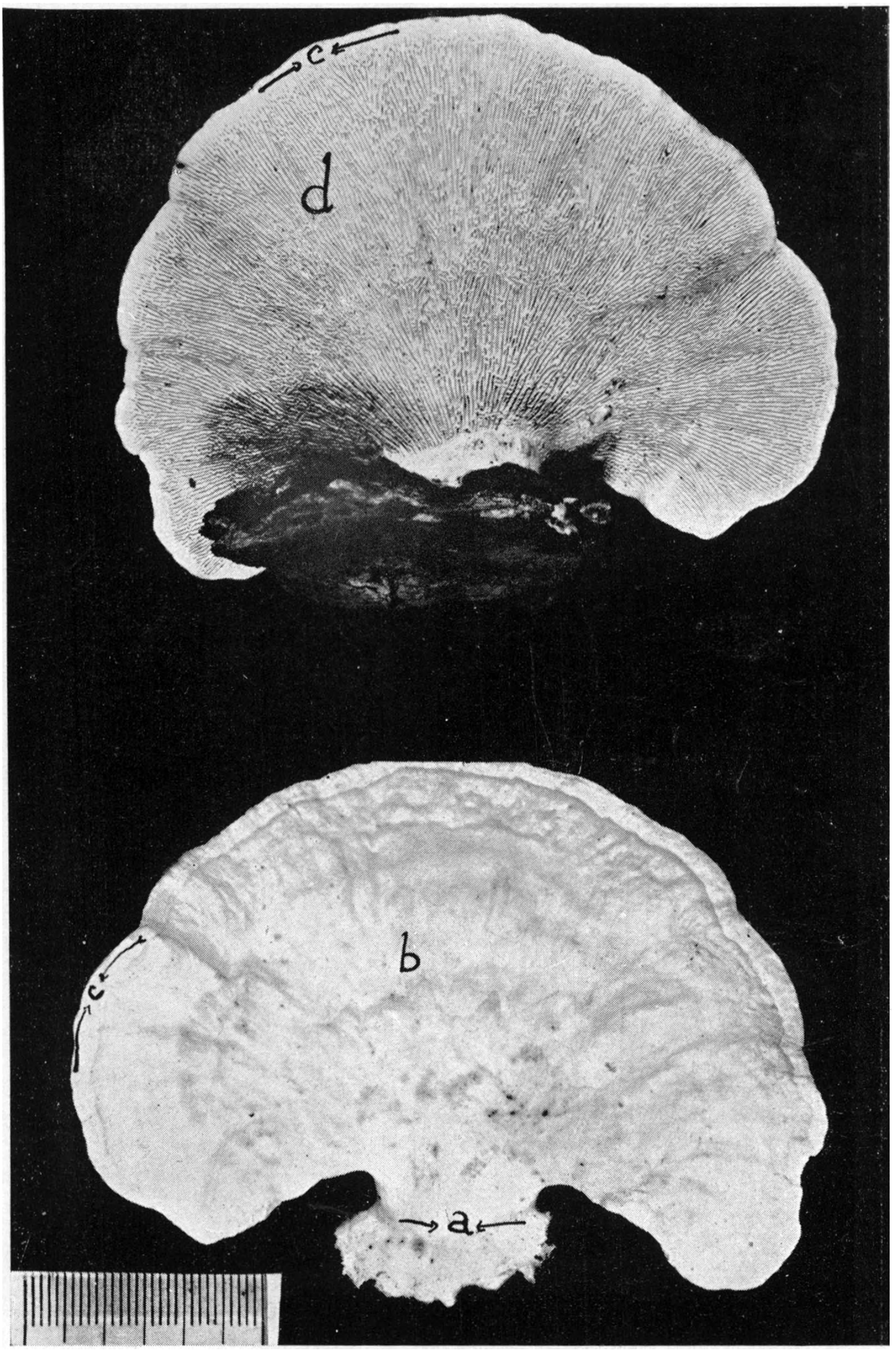

Lenzites repanda (Mont.) Fries. 
Est. XV

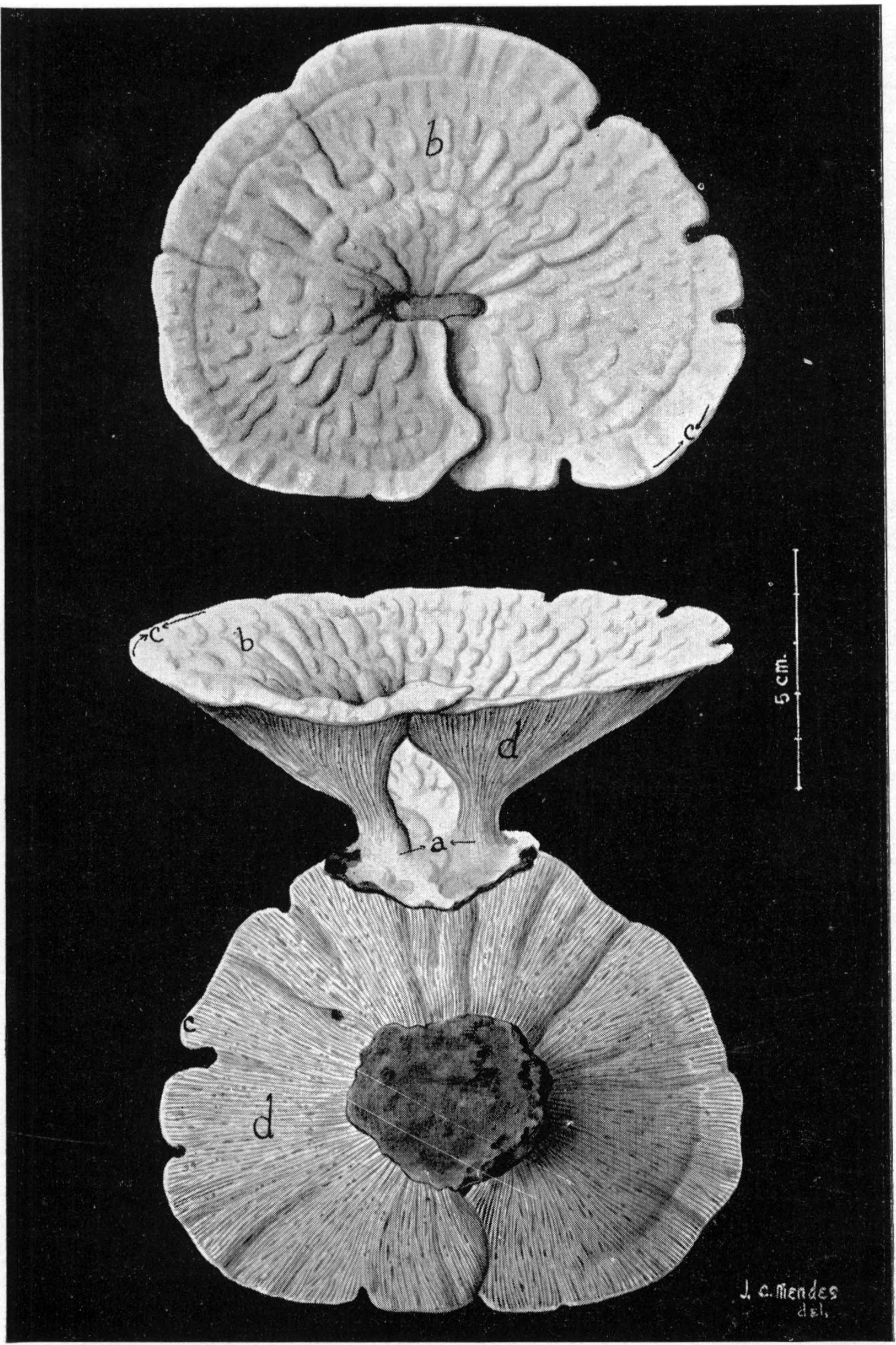


Est. XVI
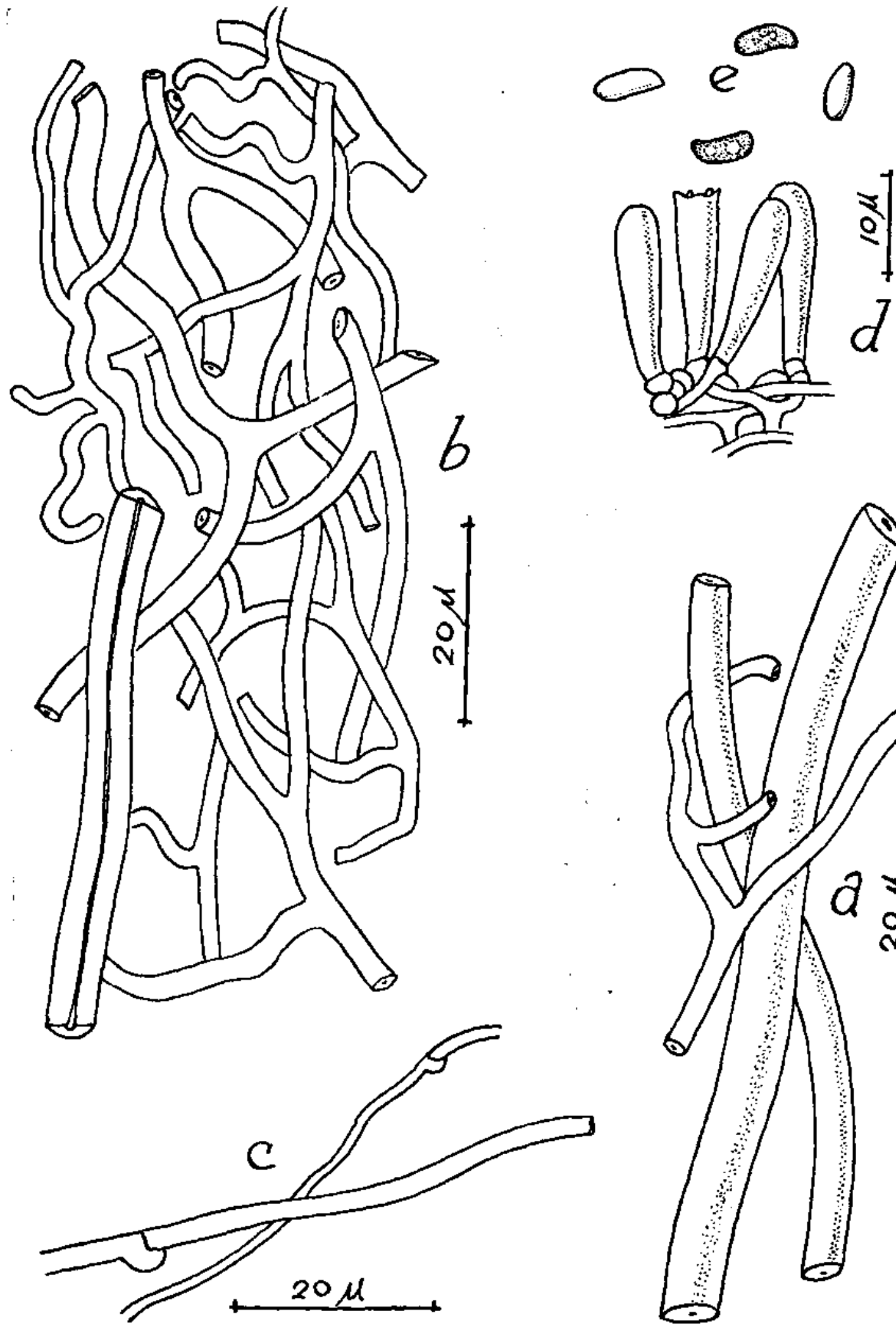

$\theta$

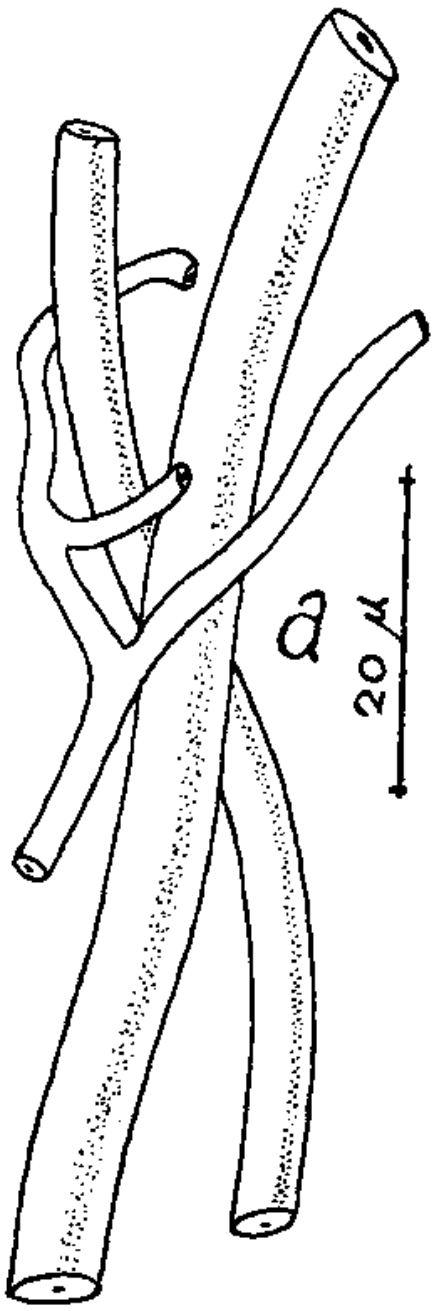

a.R.Teixeira \& J.C.mendes, del

Lenziles repanda (Mont.) Fries 
Est. XVII

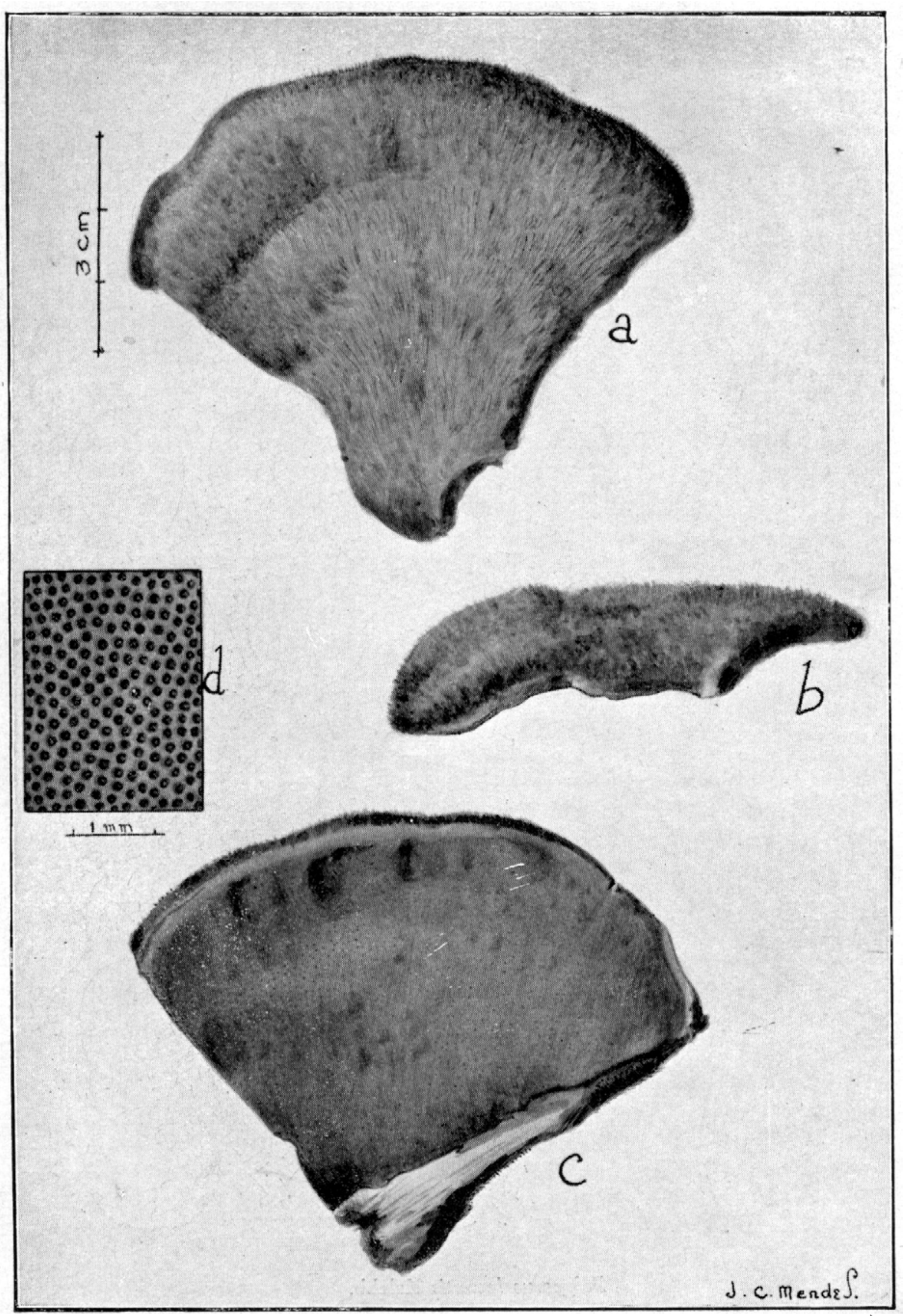

Polyporus leonotis Kalchb. 
340

$\mathrm{BRAG} \Lambda \mathrm{N}$ T I A

VoL. VI

Est. XVIII
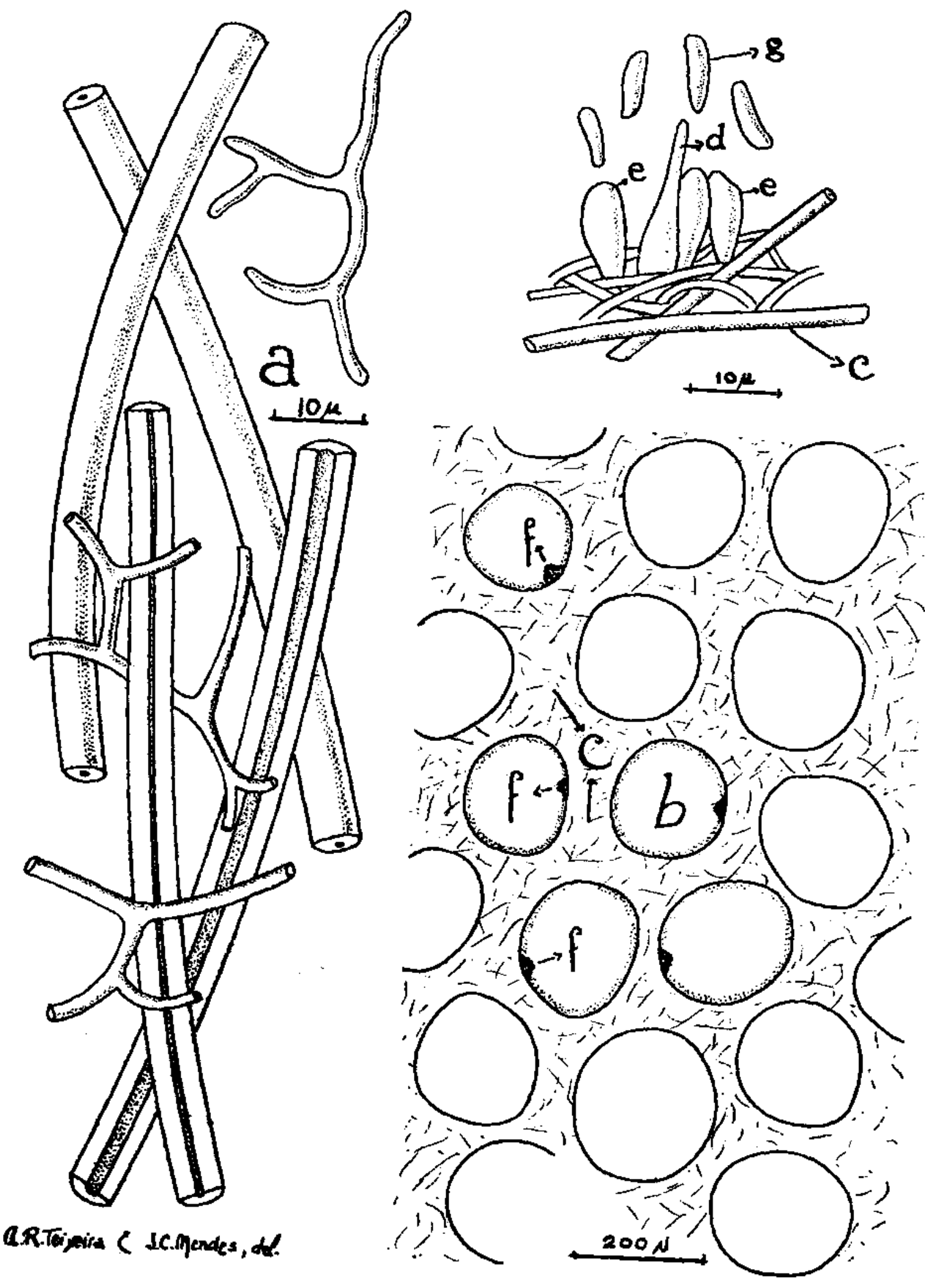

Polyporus leonotis Kalchb. 
Est. XIX

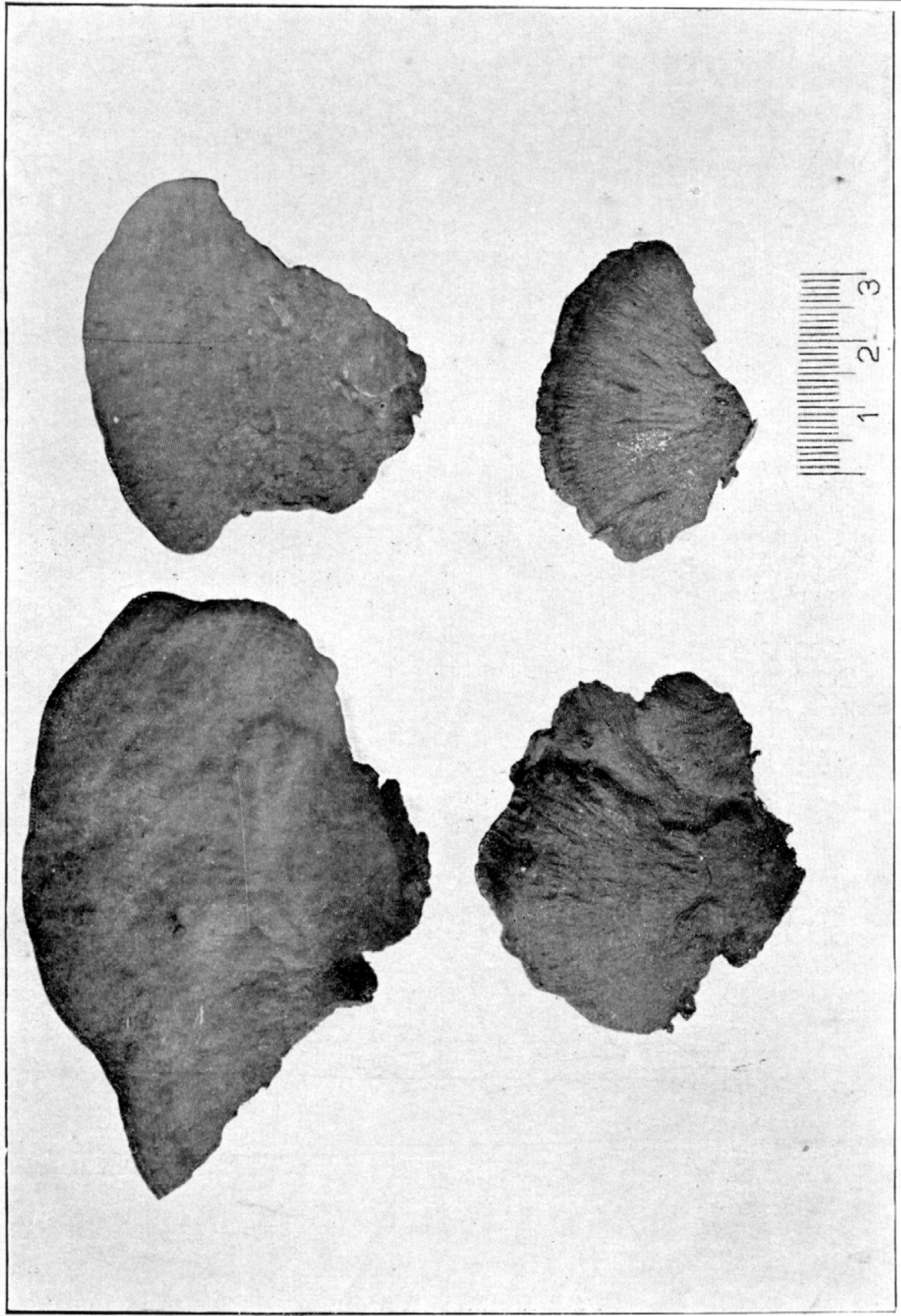

Polyporus gilvus (Schw.) Fries. 

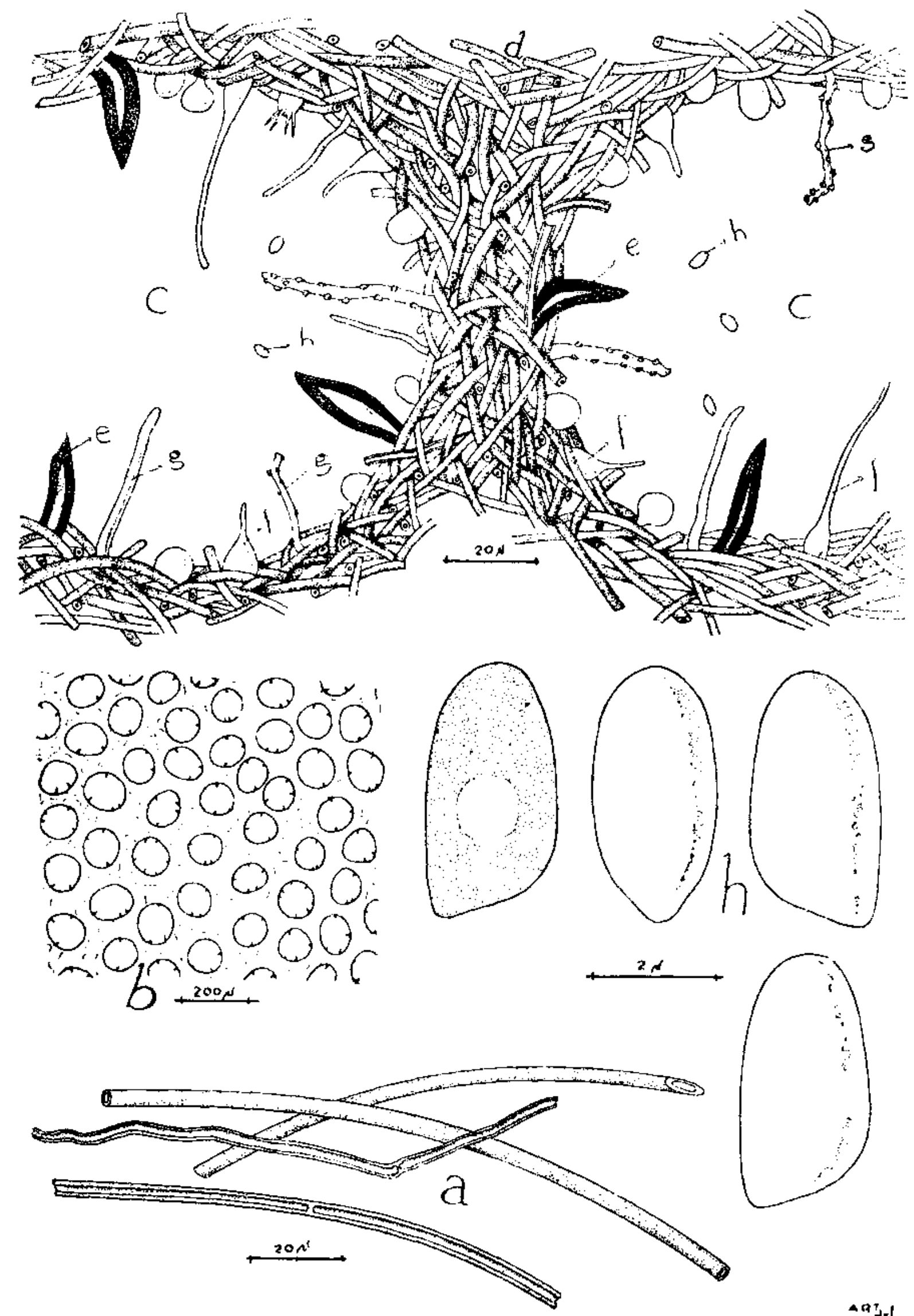

Polyporus gilvus (Schw.) Fries 
Est. XXI
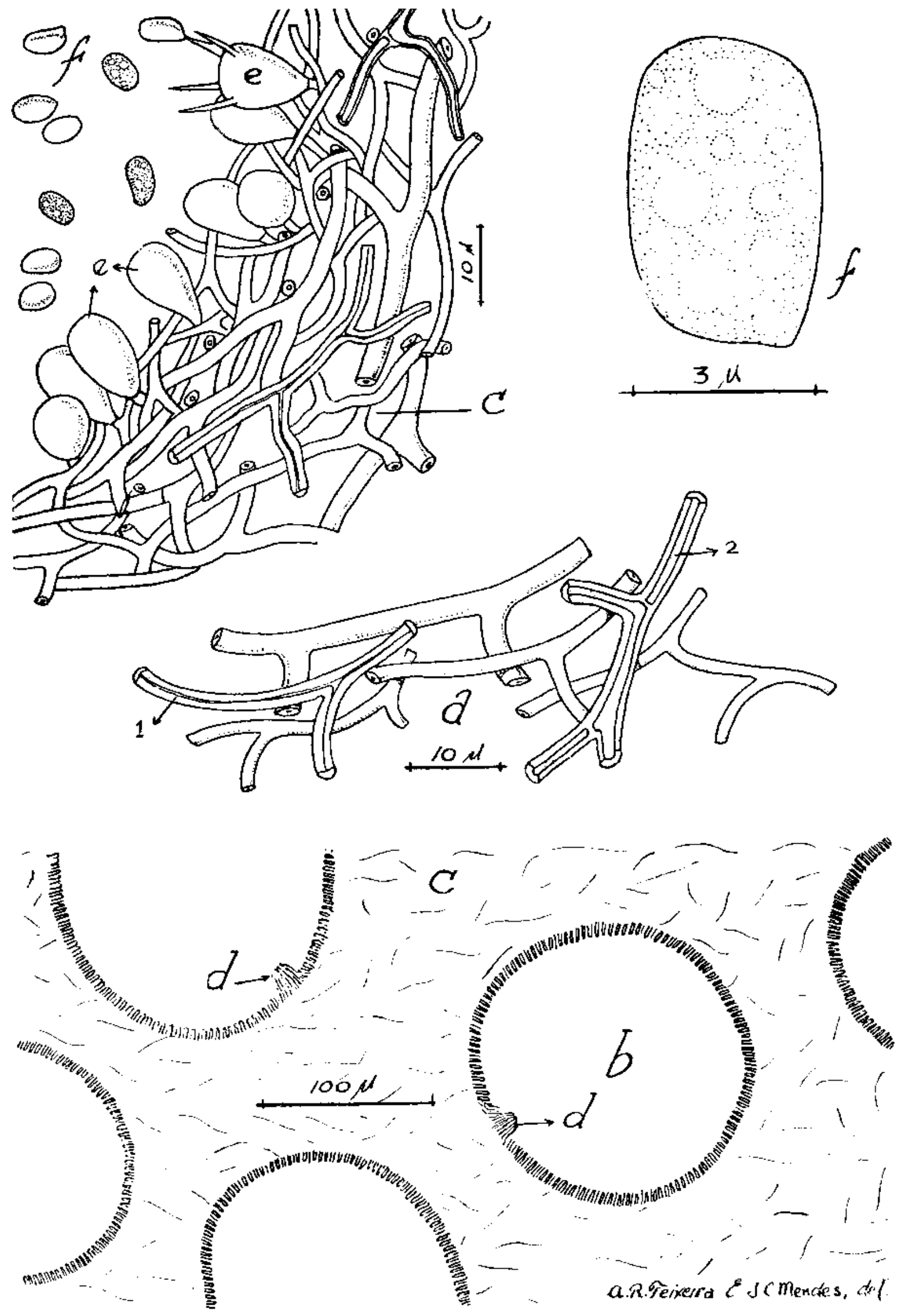
Est. XXII

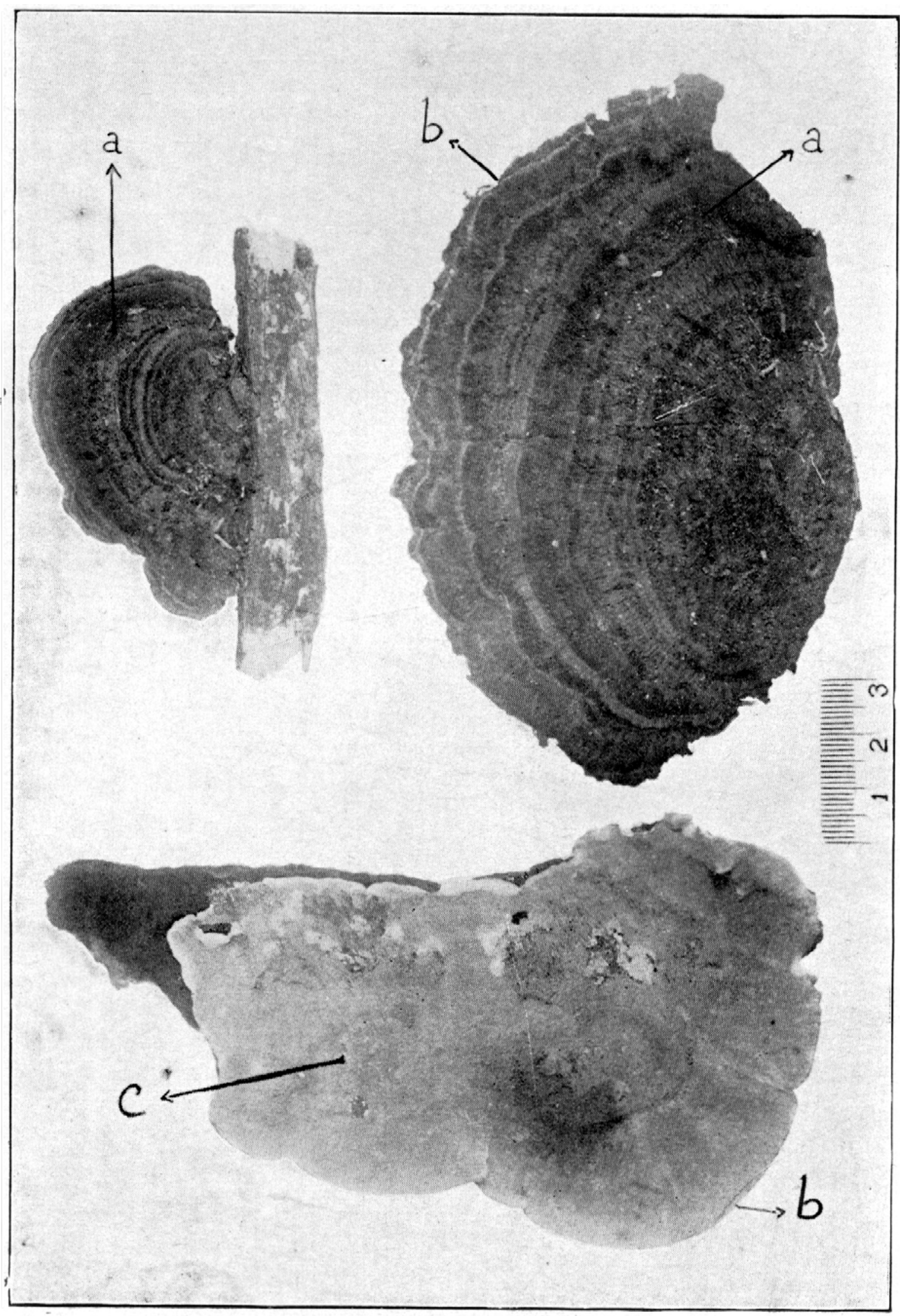


Est. XXIII
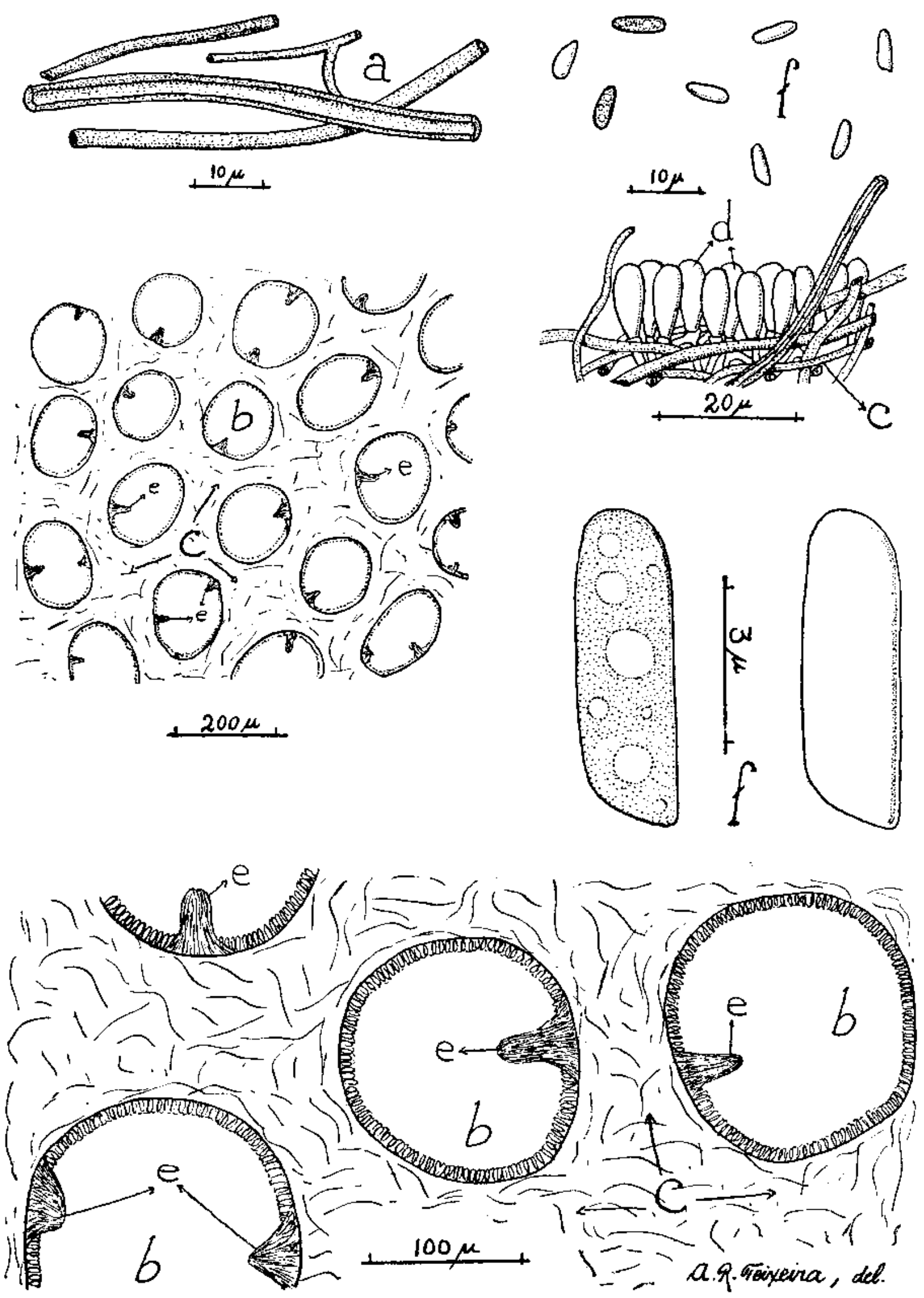


\section{ESTAMPA XXIV}

1 - píleo circular, mesópodo, infundibuliforme (de ilustração de Wettstein 14). a) pé do estipe, globoso ; b) estipe liso, glabro, cilíndrico ; c) poros ; d) margem inteira, lisa, aguda; e) substrato ; f) superfície do píleo, zonada.

2 - píleo reniforme, convexo, de estipe dorsal. a) pé do estipe, de superfície escabrosa ; b) estipe ramificado, glabro, sinuoso a noduloso ; c) superfície do píleo, glabra, radialmente enrugada com suaves rugas; d) substrato.

3 - píleo circular, mesópodo, deprimido. a) pé do estipe, de formato irregular ; b) estipe glabro, cilíndrico, liso ; c) poros ; d) margem obtusa, inteira, ligeiramente sinuosa ; e) tubos estratificados (caraterístico das fomóideas) ; f) superfície glabra, concêntricamente sulcada ; g) contexto; h) substrato.

4 - píleo espatulado, pleurópodo. a) estipe curto, glabro, liso, subcilíndrieo ; b) poros ; c) substrato.

5 - píleo irregular, infundibuliforme, de estipe excêntrico. a) estipe curto, obcônico, piloso ; b) poros ; c) margem lobada a fendida ; d) superfície glabra ; e) substrato.

6 - ṕleo petal6ide, séssil, convexo.

7 - píleo flabeliforme, séssil, convexo.

8 - píleo dimidiado, séssil, convexo.

9 - píleo circular, mesópodo, umbonado (de fotografia de Lloyd (6). a) estipe cônico, glabro, liso ; b) margem subaguda, ondulada ; c) superfície glabra, concêntricamente sulcada; d) umbo; e) substrato.

10 - píleo séssil, aplanado. a) superfície glabra, concêntrica e suavemente ondulada ; b) contexto ; c) tubos estratificados; d) margem obtusa ; e) substrato.

11 - píleo séssil, ungulado. a) superfície glabra, concêntrica e suavemente ondulada ; b) contexto ; c) tubos estratificados ; d) margem obtusa ; e) substrato.

12 - corpo-de-frutificação ressupinado (caraterístico do gênero $P$ oria). a) tubos não estratificados; b) contexto; c) substrato.

13 - corpo-de-frutificaçăo efuso-reflexo. a) superfície glabra, concêntrica e suavemente ondulada ; b) contexto; c) tubos não estratificados ; d) margem obtusa ; e) substrato.

14 - píleo séssil, conchado. a) superfície pilosa ; b) contexto ; c) tubos não estratificados ; d) margem obtusa ; e) substrato.

15 - píleo imbricado. a) superfície glabra, lisa ; b) contexto ; c) tubos não estratificados; d) substrato ; e) margem obtusa. 
Est. XXIV

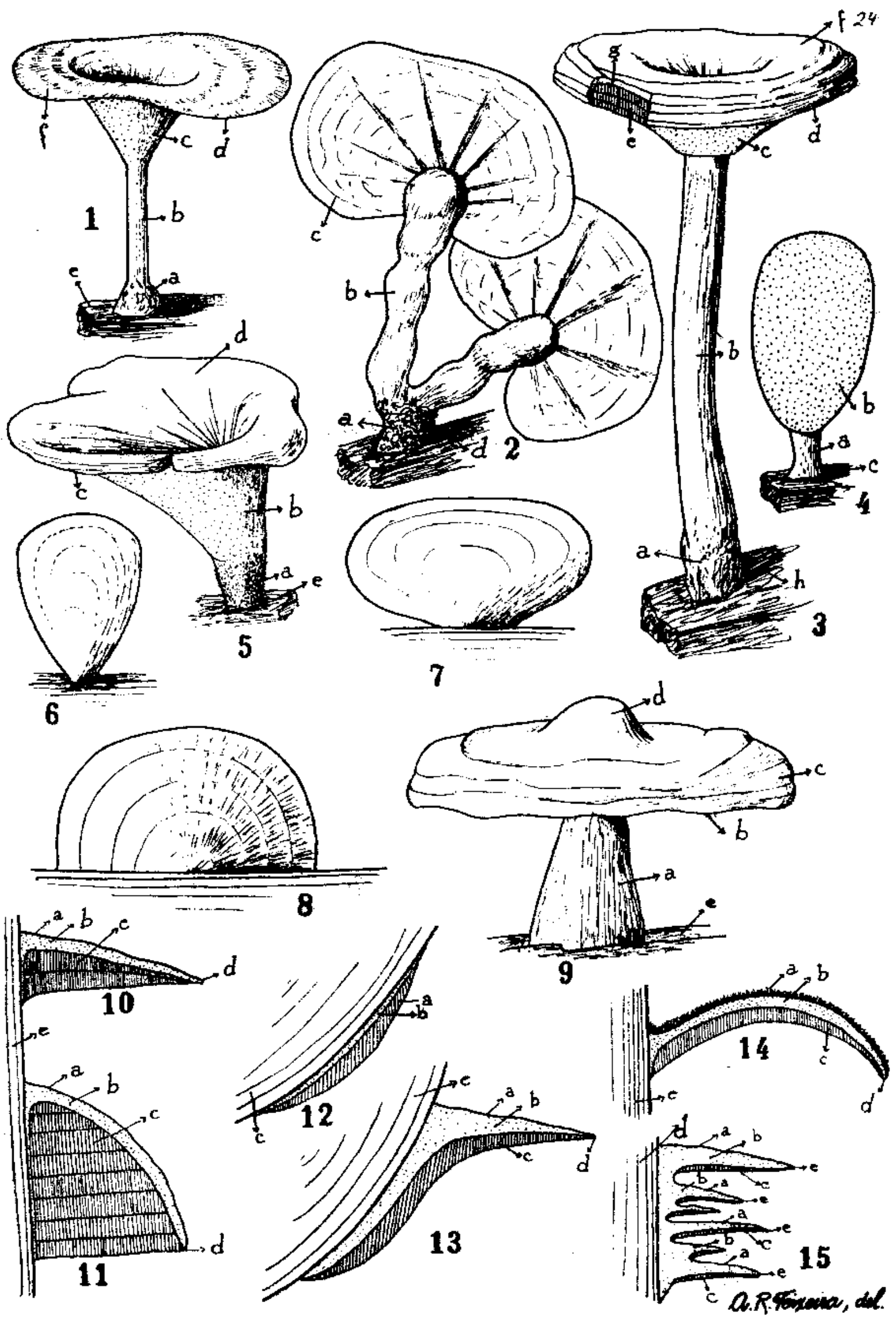




\section{ESTAMPA XXV}

16 - Trametes sp. - corte transversal mostrando os tubos a diferentès profundidades no contexto. a) superf(cie pilosa ; b) contexto; c) tubos; d) substrato.

17 - Cyclomyces sp., de uma fotografia de Lloyd (6). a) estipe obcônico ; b) poros lamelares, concêntricos, típicos do gênero ; c) superfície convexa; d) substrato.

18 - Lenzites sp. - a) poros lamelares radiais, típicos do gênero ; b) bordos suavemente sinuosos; c) substrato.

19 - Daedalea sp. - a) poros irregularmente alongados, dedalóides, típicos do gênero ; b) substrato.

20 - Poros pequenos, arredondados, típicos dos gêneros Polyporus, Fomes, Ganoderma e Trametes.

21 - Hexagona sp. - poros aumentados. Notar quão delgado é o dissepimento.

22 - Favolus sp. - poros longo-hexagonais, tendendo a lozangular, típicos do gênero.

23 - poros circulares, muito aumentados.

24 - poros alongados, muito aumentados.

25 - bordos lisos, dos poros.

26 - bordos dentados ou serrilhados, dos poros.

27 -- bordos fimbriados, dos poros.

28 - bordos lacerados, dos poros.

29 - Setas : a) ventricosas ; b) subuladas ; e) curvas. d) bas(dias ; e) dissepimento. 30 - Meda cilindrico-globosa. a) meda ; b) basidias.

31 - Medas : a) eilíndrico-cônicas ; b) cônicas. c) baśdias.

.32 - Paráfises : a) filiformes, simples; b) clavadas, simples ; c) filiformes, ramificadas ; d) cilindrieas, simples. 
Est. XXV
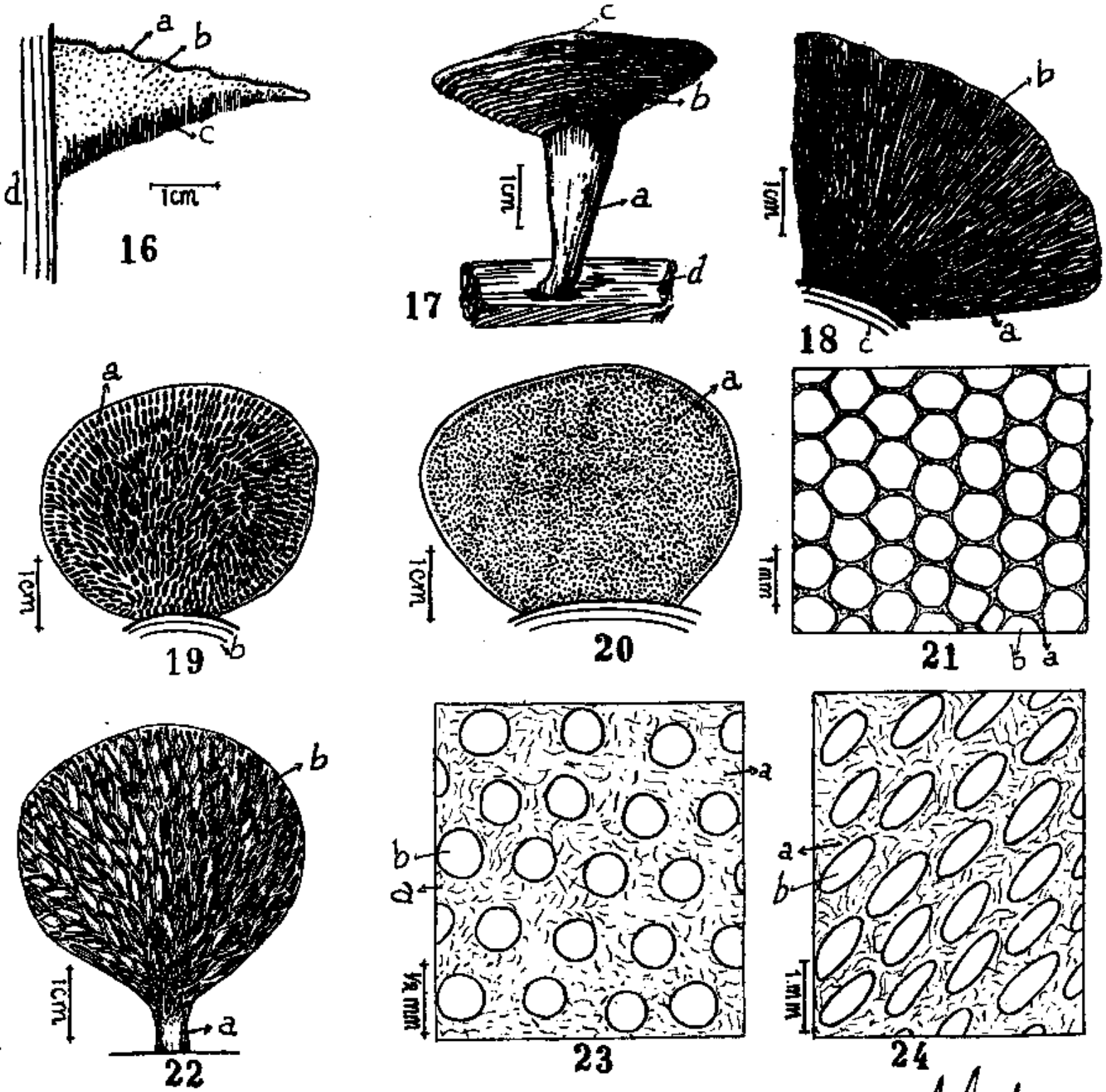

25
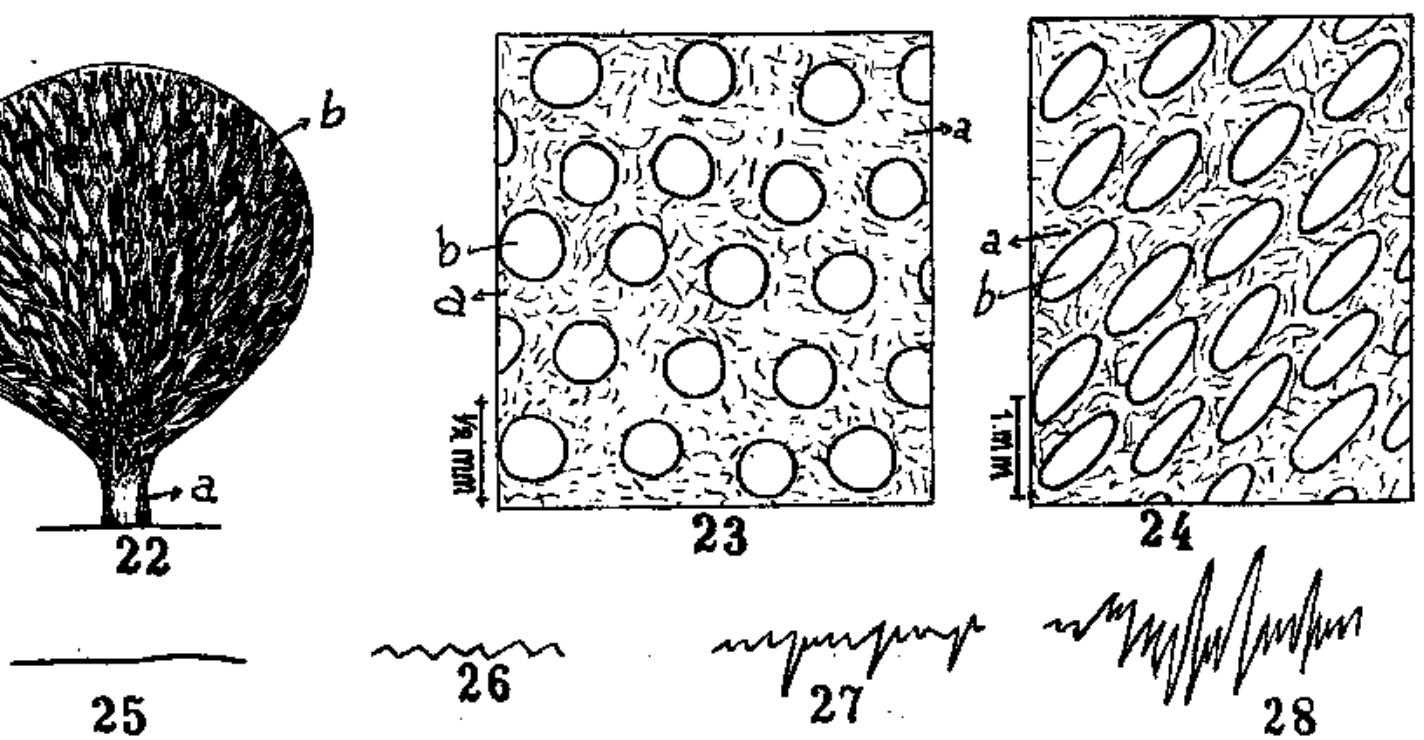

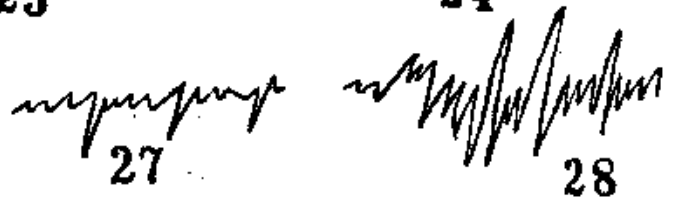
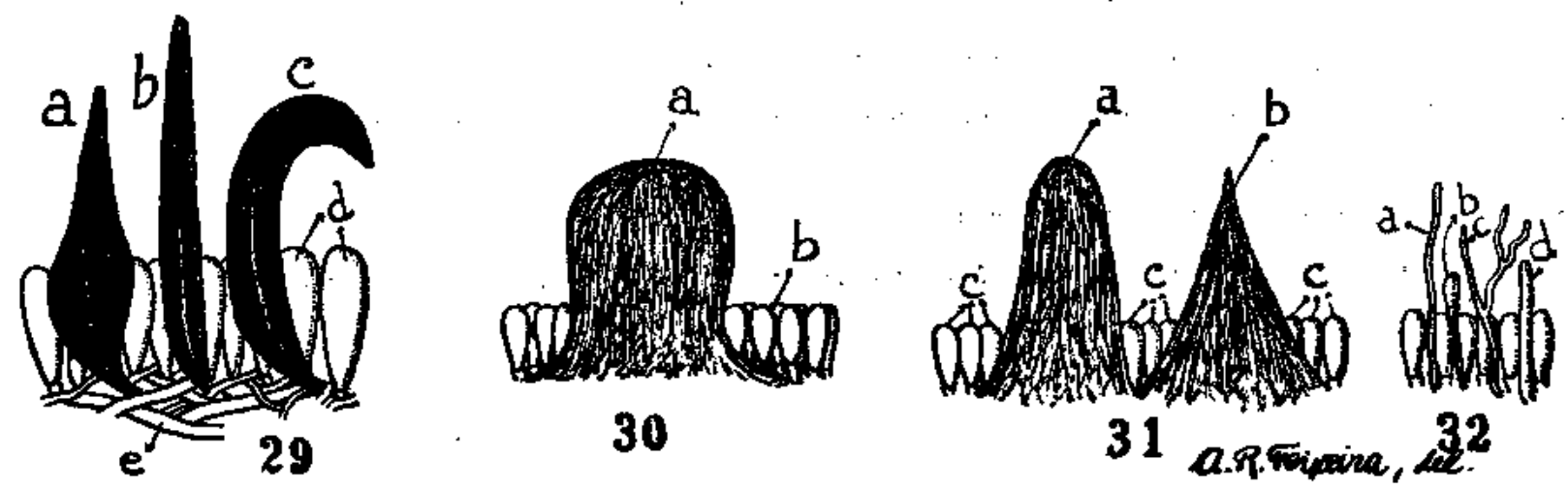


\section{ESTAMPA XXVI}

33 - basídias de Auricularia sp.

34 - basídias de Septobasidium sp. - a) probasidia

35 - basídias de Dacryomyces sp. - a) epibasídia ; b) hipobasidia

36 - basídia de Tremella sp. - de ilustração de Moeller (8).

37 - basídia de Exidia sp. - de ilustração de Moeller (8).

38 - homobasídias tipicamente clavadas; a) esterigmas.

39 - homobasidias clavado-globosas. a) esterigmas.

40 - homobasídias clavado-cilíndricas. a) esterigmas.

41 - esporo tuberculado - adaptado de Lowe (7).

42 - esporo globoso, espinulado - adaptado de Lowe (7).

43 - esporo sub-globoso, de parede espêssa, colorida (visto em corte).

44 - esporo ovóide, colorido.

45 - esporo cilfndrico-elips6ide, hislino.

46 - esporo elipsóide.

47 - esporo cilíndrico.

48 - esporo alantóide.

49 - esporo reniforme.

50 - esporo de Ganoderma (visto em corte). a) d́pice, geralmente truncado ; b) episporo ; c) endosporo.

51 - cistídia cilíndrica.

52 -. cistídia ventricosa.

53 - eistédia clavada.

54 - cistídia subglobosa.

55 - cistfdia capitada (incrustada apenas no tôpo).

56 - cistídia lanceolada.

57 - hifa lisa, hialina.

58 - bifa sinuose, fracamente colorida, näo ramificada.

59 - hifa sinuosa, profundamente colorida, pouco ramificada.

60 - hifa de parede estreita e largo lúmen. a) lómen.

61 - hifa de parede grossa e estreito lúmen. a) lúmen.

62 - hifa de parede estreita, largo lámen, septada, pouco ramificada. a) aeptos; b) límen.

63 - hifa hialina, muito ramificada.

64 - hifas com ganchos de ligação. a) antes da fusão das células ; b) logo depois da fusāo ; e) estágio finsl. 
Est. XXVI

(a)

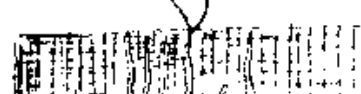
1
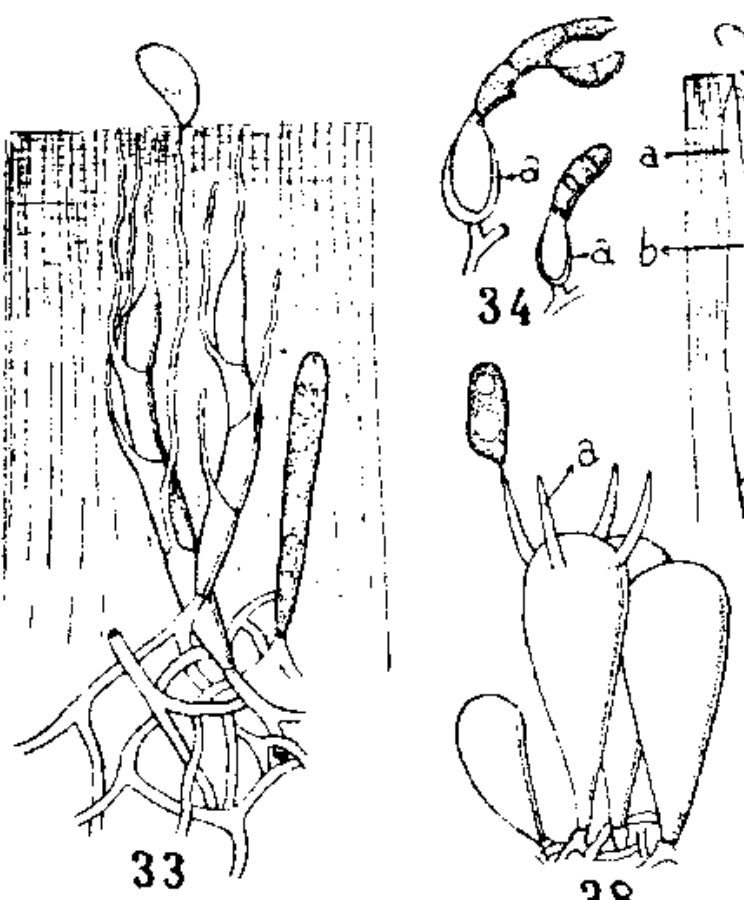

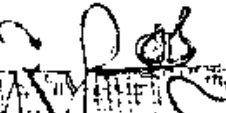
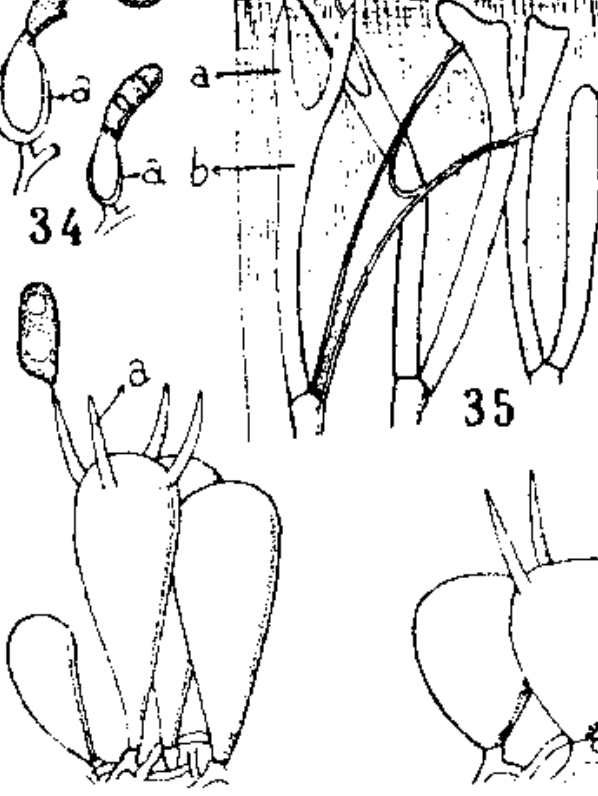

38

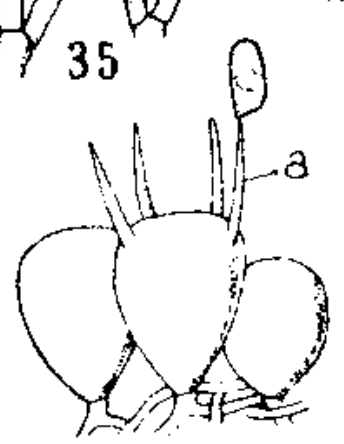

39

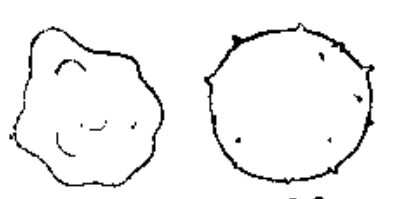

41

42
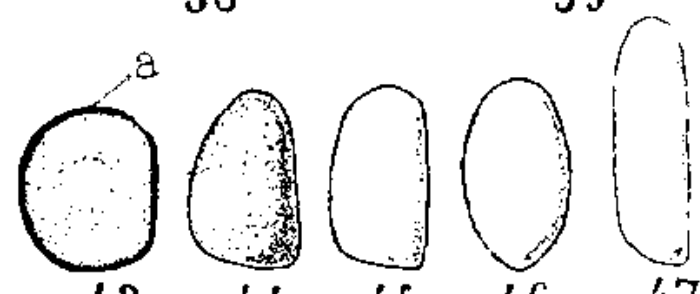

$47 \quad 48 \quad 49$
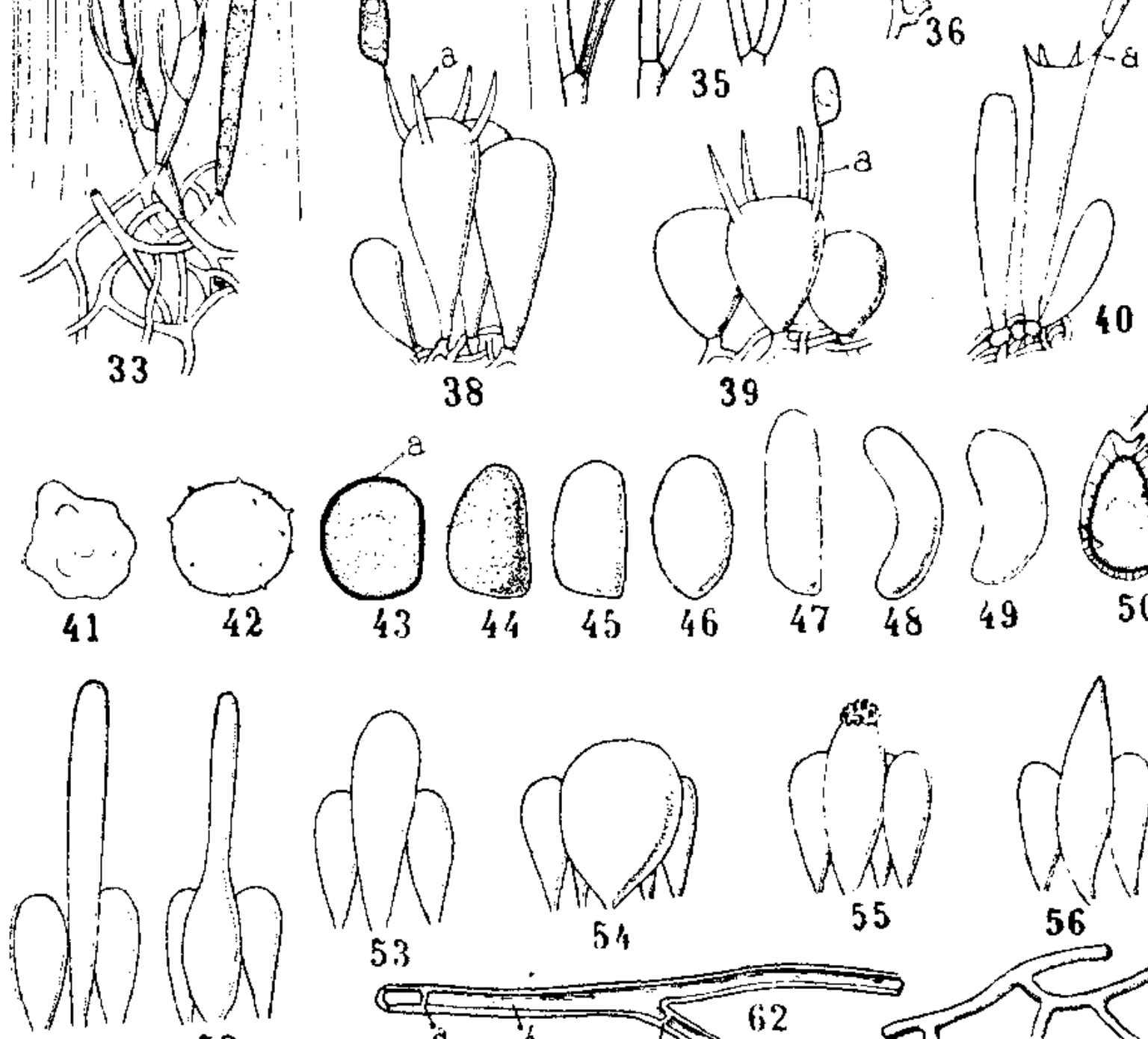

51
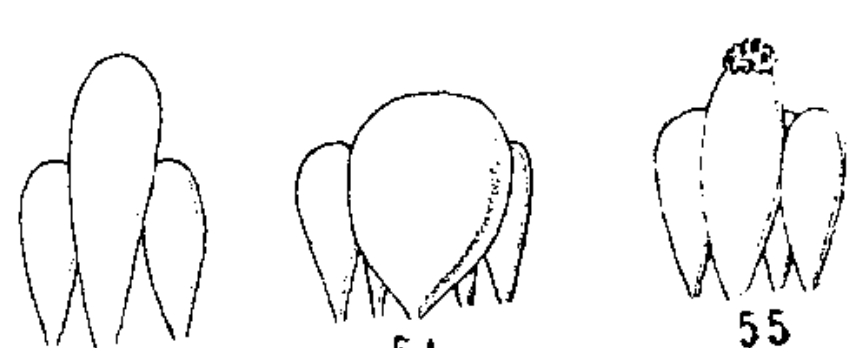

54
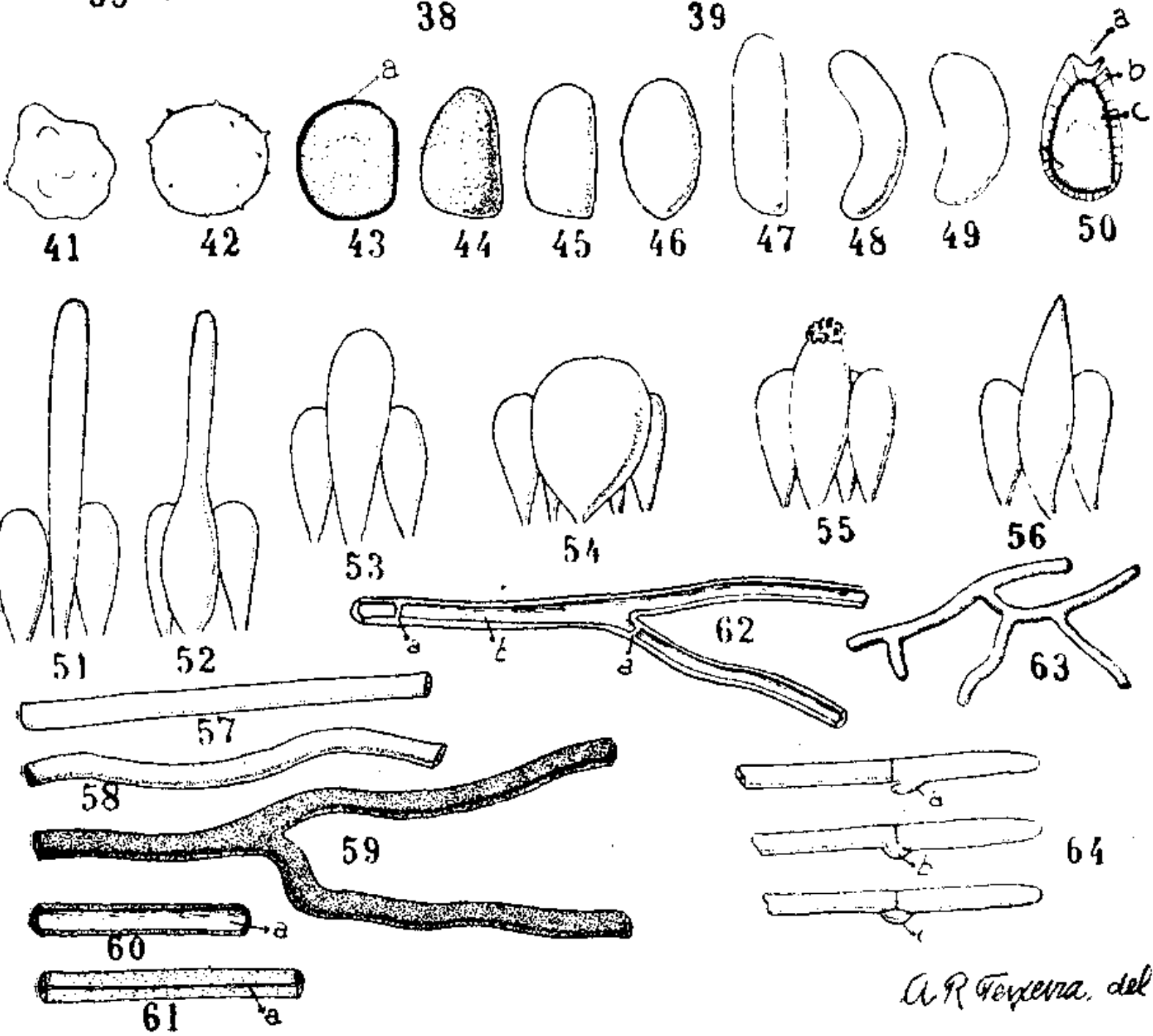

59

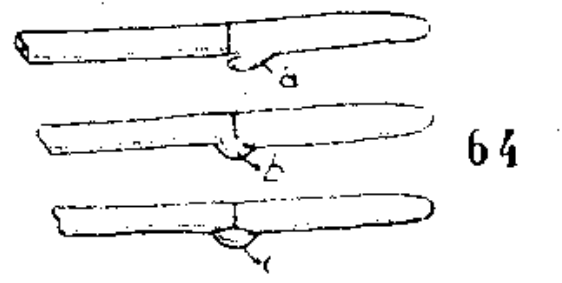

ARTrewerna del 